\title{
Placemaking, local community and tourism
}

\section{Koncept preoblikovanja mjesta, lokalna zajednica i turizam}

The challenges of modern tourism development increasingly indicate the need for new approaches based on the creative use of intangible assets and heritage, and a more harmonious relationship between the local community and tourists. Placemaking is one such approach, which goes to the core of what builds places and local communities. This paper looks at the evolution of the concept, and its approaches and definitions. Among the tools of placemaking, tangible (physical design), intangible (mental images), and mixed approaches are recognized. The examples in this paper have been selected mainly from tourism and community development studies. Quality placemaking leads to the development of a sense of place, increases social cohesion, and stimulates the long-term regeneration of public spaces, which contributes to tourism attractiveness. In this light, the concept of placemaking can serve as a useful analytical category for more systematic research on spatial transformations and as a development tool in strategic tourism planning.

Key words: placemaking, local community, spatial planning, tourism
Izazovi suvremenoga turističkog razvoja sve više upućuju na potrebu za novim pristupima koji se temelje na kreativnom korištenju nematerijalnih vrijednosti i baštine te skladnijem odnosu između lokalne zajednice i turista. Koncept preoblikovanja mjesta (engl. placemaking) jedan je od takvih pristupa koji prodire u srž onoga što gradi mjesta i lokalne zajednice. U ovom radu obrađuje se evolucija pojma, pristupi te definicije s obzirom na ključne elemente (priroda koncepta, lokalna zajednica, prostor, ostale teme). Među alatima preoblikovanja mjesta kroz niz primjera, posebice iz područja turizma te razvoja zajednice, prepoznaju se materijalni (dizajn prostora), nematerijalni (mentalne slike) i mješoviti. Kvalitetan placemaking rezultira razvojem osjećaja mjesta, povećava socijalnu koheziju te stimulira dugoročnu regeneraciju javnih prostora. Navedeno doprinosi i turističkoj atraktivnosti prostora te kvaliteti suživota lokalne zajednice i turista. S obzirom na sve navedeno, koncept preoblikovanja mjesta može poslužiti kao korisna analitička kategorija za istraživanje prostornih transformacija, ali i kao razvojni alat u strateškom planiranju turizma.

Ključne riječi: preoblikovanje mjesta, lokalna zajednica, prostorno planiranje, turizam 


\section{Introduction}

Recent reflections on tourism within social sciences have brought creativity (Richards, 2011; Jelinčić and Senkić, 2017; Duxbury and Richards, 2019), intangible assets and cultural heritage (Pritchard et al., 2011; Marques and Richards, 2014; Duxbury et al., 2019), and the dynamics of relationships between local communities and tourists (Pearce and $\mathrm{Wu}, 2015$; Richards, 2017b) to the fore. As a result, quality of life for the local community is now considered an increasingly important element of tourism planning (van der Borg et al., 1996; Hampton, 2005). This, in turn, means that the local community will have a positive attitude towards tourism development whereas the tourists will get a quality experience. The creative approach, as it is widely understood (Kelkar and Spinelli, 2016; Gallagher and Ehlman, 2019), comprises a wide range of responses to the social challenges that modern tourism poses, thus contributing to the integral development and revitalization of place and the local community (Grodach et al., 2014; Mokras-Grabowska, 2014; Murdoch III et al., 2016; Redaelli, 2018; Gallagher and Ehlman, 2019). Creativity used to be limited to building an attractive image of a place (and its community) through place branding. Lately, however, the necessity of getting to the core of what builds places and local communities has become increasingly recognized (Richards, 2017b; Richards and Duif, 2018). This review paper discusses one such approach - the concept of placemaking ${ }^{1}$ - which is based on the local community's engagement and the direct effect it has on the quality of life in the community. The aim of this paper is to provide a critical overview of domestic and foreign empirical and review papers regarding the concept of placemaking. Given the wide range of topics and disciplines related to placemaking, this paper is based on an analysis of the papers of the most relevant authors, according to citation databases and the general importance of their work in social sciences and humanities. Paper selection was primarily lim-

\footnotetext{
1 In this paper, the English term placemaking was translated into Croatian as preoblikovanje mjesta (place-redesign) which is a better suited equivalent (than a direct translation), because in Croatian geography spatial changes, transformations, planning interventions, etc. of existing places are thought of as being redesigns, rather than (new) creations. However, it should be noted that the term placemaking has also been translated as stvaranje mjesta/grada (city-making) in Croatian scientific literature. This will be discussed in more detail below.
}

\section{Uvod}

Novija promišljanja turizma u okviru društvenih znanosti sve više ističu važnost kreativnosti (Richards, 2011; Jelinčić i Senkić, 2017; Duxbury i Richards, 2019), nematerijalnih vrijednosti i baštine (Pritchard i dr., 2011; Marques i Richards, 2014; Duxbury i dr., 2019) te posebno dinamiku odnosa između lokalne zajednice i turista (Pearce i Wu, 2015; Richards, 2017b). Posljedično je promišljanje kvalitete života lokalnoga stanovništva kao jamca njegova pozitivnoga stava prema turističkom razvoju, a time i kvalitetnoga turističkog doživljaja, sve prisutniji element strateškoga planiranja turizma (van der Borg i dr., 1996; Hampton, 2005). Široko shvaćen kreativni pristup (Kelkar i Spinelli, 2016; Gallagher i Ehlman, 2019) zahvaća čitav spektar odgovora na društvene izazove koje postavlja suvremeni turizam te tako doprinosi integralnom razvoju i revitalizaciji, kako prostora tako i lokalne zajednice (Grodach i dr., 2014; Mokras-Grabowska, 2014; Murdoch III i dr., 2016; Redaelli, 2018; Gallagher i Ehlman, 2019). No dok se kreativnost nekad iscrpljivala ponajviše u pokušaju izgradnje privlačna imidža prostora (i zajednice) kroz brending mjesta (engl. place branding), u posljednje vrijeme sve se više prepoznaje neophodnost zahvaćanja u srž onoga što gradi mjesta i lokalne zajednice (Richards, 2017b; Richards i Duif, 2018). U ovom radu bit će govora o jednom takvom pristupu, konceptu preoblikovanja mjesta (engl. placemaking) ${ }^{1}$ koji se temelji na uključenosti lokalne zajednice i izravnom djelovanju na kvalitetu života. Cilj je rada izrada kritičkoga prikaza domaćih i stranih empirijskih i preglednih istraživanja o navedenom konceptu preoblikovanja mjesta. S obzirom na širok spektar tema i disciplina koje se dotiču koncepta preoblikovanja mjesta, ovaj se rad temelji na analizi radova najrelevantnijih autora prema citatnim bazama, ali i općem značaju njihovih djela u društvenim i humanističkim znanostima. Izbor radova ograničen je na one koji se

\footnotetext{
$1 \mathrm{U}$ ovom se radu engleski pojam placemaking prevodi kao preoblikovanje mjesta pod pretpostavkom da taj izraz bolje odgovara u hrvatskoj geografiji uvriježenom pristupu u kojem se prostorne promjene, transformacije, planske intervencije i slično u već postojećim mjestima smatraju njihovom preobrazbom, a ne činom njihova stvaranja. No valja napomenuti da se pojam placemakinga u hrvatskoj literaturi već nalazi u prijevodu stvaranje mjesta/grada, o čemu će više riječi biti u nastavku.
} 
ited to those papers explicitly discussing the topic of placemaking, and those that emphasize the link between placemaking practices and tourism, especially from geographical point of view.

\section{The evolution of the term and definitions of placemaking}

The idea behind placemaking is as old as human civilization (Ghavampour and Vale, 2019), as people have always had the intrinsic need to make the spaces that surround them meaningful. However, many authors (Razali and Ismail, 2014; Balassiano and Maldonado, 2015; Redaelli, 2016; Richards, 2017b; Sofield et al., 2017; Strydom et al., 2018; Ghavampour and Vale, 2019; Laven et al., 2019) agree that placemaking as practiced today only dates back to the 1960's with the first reactions to postwar urban planning in American cities. The urban planning practices at the time created isolated city spaces with lower quality of life (Sofield et al., 2017). With the emergence of what Relph (1976) called "placelessness," pioneers Jane Jacobs and William H. Whyte advocated focusing on people (Razali and Ismail, 2014). As a result, creating quality surroundings and public spaces became a priority (Zukin, 2010; Richards, 2017b). Aside from the social-usage tradition of thought in planning, Ghavampour and Vale (2019) also outlined the so-called visual-artistic tradition of thought, influenced by C. Sitte (2010, original work 1889) and his work City Planning According to Artistic Principles. This work highlights the visual and esthetic experience of place and was very influential in shaping the concept of placemaking.

The American Project for Public Spaces nonprofit organization was directly influenced by William H. Whyte's work. It was founded with the goal of creating public spaces that build communities, and it is still considered among the most significant organizations in promoting placemaking. Within the United States, there is also ArtPlace, a consortium of national foundations, government agencies, and banks, and the National Endowment for the Arts federal agency known for its creative placemaking grant program (Our Town) used to support artistic interventions in the United States. On a global izravno bave konceptom preoblikovanja mjesta te one u kojima je istaknuta veza između praksi preoblikovanja mjesta i turizma, osobito s geografskoga aspekta.

\section{Evolucija pojma i definicije preoblikovanja mjesta}

Iako je ideja koja počiva iza koncepta preoblikovanja mjesta zacijelo stara koliko i ljudska civilizacija (Ghavampour i Vale, 2019), uzimajući u obzir intrinzičnu čovjekovu potrebu za osmišljavanjem prostora koji ga okružuje, velik broj autora (Razali i Ismail, 2014; Balassiano i Maldonado, 2015; Redaelli, 2016; Richards, 2017b; Sofield i dr., 2017; Strydom i dr., 2018; Ghavampour i Vale, 2019; Laven i dr., 2019) slaže se da korijene koncepta treba tražiti u 60-im godinama prošloga stoljeća, kad se javljaju prve reakcije na poslijeratno urbano planiranje američkih gradova. Za razliku od dotadašnjega planiranja, koje je rezultiralo stvaranjem izoliranih gradskih prostora, smanjenjem kvalitete života (Sofield i dr., 2017) te pojavom onoga što Relph (1976) naziva bezmjesnošću, pioniri nove misli Jane Jacobs i William H. Whyte zalažu se za stavljanje ljudi u fokus (Razali i Ismail, 2014) zahvaljujući čemu osmišljavanje kvalitetnoga životnog okruženja, te stoga i javnih prostora, postaje prioritet (Zukin, 2010; Richards, 2017b). Osim ove društveno korisne tradicije u planiranju, Ghavampour i Vale (2019) navode i tzv. vizualno-umjetničku struju, na čelu s C. Sitteom (2010, izvornik 1889) i njegovim djelom Gradogradnja prema umjetničkim načelima, kao onu koja je ističući vizualne kvalitete i estetski doživljaj prostora, izvršila utjecaj na sam koncept preoblikovanja mjesta.

William H. Whyte izravno je utjecao na osnivanje neprofitne američke organizacije Project for Public Spaces s ciljem stvaranja javnih prostora koji izgrađuju zajednicu, a koja se i danas smatra jednim od najvažnijih promicatelja koncepta preoblikovanja mjesta. Uz njih se u američkom kontekstu ističe i konzorcij nacionalnih zaklada, vladinih agencija i banaka ArtPlace te federalna agencija National Endowement for the Arts, koja osobito svojim programom subvencija pod nazivom Our Town podupire umjetničke intervencije vezane za kreativno preoblikovanje mjesta u SAD-u. Na globalnoj razini djeluje
Placemaking, local community and tourism

Koncept preoblikovanja mjesta, lokalna zajednica i turizam 
scale, there is the Placemaking Fund nonprofit organization. They started Placemaking $X$ and Social Life Project, initiatives that call for social and environmental change. Within Europe, the network for placemaking -Placemaking Europe- connects scientists, experts, decision makers, and community leaders. Similar programs are also financed by the European Cultural Foundation and the Robert Bosch Foundation.

Because of its wide use in the context of different fields, defining placemaking often seems complex and challenging. The term itself can be confusing and contradictory (Wyckoff, 2014; Razali et al., 2019), debatable (Razali et al., 2019), and with no clear limits (Dupre, 2019; Zitcer, 2020), which can largely undermine its utility in various areas ( $\mathrm{Wy}-$ ckoff, 2014).

Various authors (Lew, 2017; Sofield et al., 2017; Strydom et al., 2018; Dupre, 2019; Razali et al., 2019; Zhao, 2019) have confirmed that the concept is not limited to only one field (Friedman, 2010; Strydom et al., 2018). In fact, there are over 20 scientific fields that deal with placemaking; they are as follows: architecture; urban design; landscape architecture; geography; sociology; tourism; social anthropology; psychology; spatial planning; philosophy; economy; public policy; technology; political science; marketing; management; media; culture; cognitive sciences; law; ecology; art; education; and music. Razali et al. (2019) argue that placemaking has been widely utilized in the fields that explore the relationships between places and people. Their qualitative analysis of research papers dealing with this topic in Malaysia shows that most papers are from the fields of spatial planning and tourism. This is followed by the papers from the fields of marketing, geography, and architecture. This paper primarily references other papers published in journals from the fields of spatial planning and urban design, followed by journals dealing with tourism and tourism management, geography, arts and culture, event management, sociology, architecture, public policy, etc.

Sofield et al. (2017) argue that placemaking in tourism is primarily limited to the reconstruction of image for marketing purposes. In other words, using neprofitna organizacija Placemaking Fund koja svojim inicijativama Placemaking $X$ i Social Life Project doprinosi pozitivnim promjenama na društvenom i okolišnom planu. U Europi konceptu preoblikovanja mjesta najviše pozornosti posvećuje mreža Placemaking Europe koja povezuje znanstvenike, stručnjake, donositelje odluka te lokalne čelnike, a programe sa sličnim predznakom financiraju i zaklade poput $\mathrm{Eu}$ ropske kulturne zaklade i Zaklade Robert Bosch.

Zbog široke upotrebe u kontekstima različitih disciplina definiranje koncepta preoblikovanja mjesta često se čini složenim i zahtjevnim zadatkom, a sam pojam označava se kao zbunjujući i kontradiktoran (Wyckoff, 2014; Razali i dr., 2019), nejasnih granica (Dupre, 2019; Zitcer, 2020) i diskutabilan (Razali i dr., 2019), što u velikoj mjeri može umanjiti njegov doprinos u raznim područjima primjene (Wyckoff, 2014).

Da je riječ o konceptu koji nije ograničen na jednu disciplinu (Friedmann, 2010; Strydom i dr., 2018), potvrđuje niz autora (Lew, 2017; Sofield i dr., 2017; Strydom i dr., 2018; Dupre, 2019; Razali i dr., 2019; Zhao, 2019) koji su pregledom literature prepoznali više od 20 znanstvenih disciplina koje se bave konceptom preoblikovanja mjesta. Riječ je o sljedećim disciplinama: arhitektura, urbani dizajn, krajobrazna arhitektura, geografija, sociologija, turizam, socijalna antropologija, psihologija, prostorno planiranje, filozofija, ekonomija, javne politike, tehnologija, političke znanosti, marketing, menadžment, mediji, kultura, kognitivne znanosti, pravo, ekologija, umjetnost, obrazovanje i glazba. Razali i dr. (2019) tvrde da se koncept preoblikovanja mjesta najviše koristi u onim znanstvenim disciplinama koje se izravno bave istraživanjem odnosa između prostora i ljudi, a njihova kvalitativna analiza znanstvenih radova o ovoj temi u Maleziji pokazuje najveću zastupljenost radova iz područja prostornoga planiranja i turizma te potom marketinga, geografije i arhitekture. S obzirom na časopise u kojima su objavljeni korišteni znanstveni radovi u ovom su radu najviše zastupljene discipline prostornoga planiranja i urbanoga dizajna, potom turizma i turističkoga menadžmenta, geografije, umjetnosti i kulture, menadžmenta događanja, sociologije, arhitekture, javnih politika i dr.

Sofield i dr. (2017) smatraju kako je korištenje pojma preoblikovanja mjesta u kontekstu turizma primarno ograničeno na rekonstrukciju imidža za 
the effects and outcomes of placemaking without being actively engaged in the process. They suggest using the terms "place-selling" or "place-marketing by tourism" instead in this case (Sofield et al., 2017, 20).

Placemaking is often described as interdisciplinary, multidisciplinary, and transdisciplinary (Sofield et al., 2017). However, through a systematic quantitative literature review of research published on placemaking in the last 25 years, i.e. through 2016, Dupre (2019) ascertained that, besides the obvious symbiotic relationship between tourism and urban initiatives, most research papers belong to only one discipline. The same conclusion was reached while doing research for this paper.

Taking everything into consideration, it seems quite challenging to define placemaking and a considerable number of authors have made attempts at doing it, emphasizing different elements of the concept. The content analysis of all the relevant papers that define placemaking showed certain similarities, as well as differences in understanding the core of the concept. We recognized four main themes: nature of the concept; local community; place; and other (Tab. 1).

Most authors agree that placemaking is a form of participatory spatial and urban planning. It includes both the public and private sector, as well as civic organizations and tourists (Marques and Richards, 2014; Thurlow and Jaworski, 2014; Baka, 2015) and particularly the general public, i.e. citizens. According to Ellery and Ellery (2019), the lowest rung on Arnstein's ladder of citizen participation that could be considered a placemaking process is the level of partnership. The synergy between cross-sectoral cooperation and the engagement of the local community (Laven et al., 2019) is at the core of placemaking. Placemaking is often described as a holistic approach, partly because it involves a wide presence of different social groups engaged in the process of planning, but also because it deals with a wide range of social and spatial challenges (Ball, 2014), which are its main focus. Richards (2017b, 2) outlines that placemaking is "a complete social practice that involves physical change, as well as changes in thinking and doing." In line with marketinške svrhe, to jest korištenje učinaka i ishoda preoblikovanja mjesta, bez aktivnoga angažmana u procesu, te kao prikladniji naziv u tom slučaju predlažu pojmove "turističkoga marketinga mjesta” ili „prodaje mjesta" (engl. place selling) (Sofield i dr., 2017,20).

Iako se narav koncepta preoblikovanja mjesta opisuje kao interdisciplinarna, multidisciplinarna i transdisciplinarna (Sofield i dr., 2017), sustavnim kvantitativnim pregledom istraživanja na temu preoblikovanja mjesta u razdoblju od 25 godina (do 2016. godine) Dupre (2019) ustanovljuje da je, izuzev očite simbioze između turizma i urbanih inicijativa, većina znanstvenih radova jednodisciplinarna, što je potvrđeno i ovim pregledom istraživanja.

S obzirom na sve navedeno definirati koncept preoblikovanja mjesta doima se pravim pothvatom u kojem se okušao nemali broj autora, stavljajući različite naglaske na pojedinačne elemente koji čine njegovu osnovu. Sadržajna analiza relevantnih radova o definiciji koncepta preoblikovanja mjesta pokazala je određene sličnosti, ali i razlike u shvaćanju srži koncepta. Glavne prepoznate teme grupirane su u četiri skupine koje se ističu po zastupljenosti: priroda koncepta, lokalna zajednica, prostor te ostale teme (tab. 1).

Što se tiče same prirode koncepta, ono oko čega se slaže najveći broj autora jest da je riječ o participativnom obliku planiranja prostora koji uključuje javni i privatni sektor te civilne udruge, često i same turiste (Marques i Richards, 2014; Thurlow i Jaworski, 2014; Baka, 2015) te, prije svega, javnost, to jest građanstvo. Prema Ellery i Ellery (2019) najniža prihvatliiva razina sudjelovanja lokalne zajednice unutar koncepta preoblikovanja mjesta na Arnsteinovim ljestvama jest razina partnerstva. Upravo sinergija međusektorske suradnje te uključivanje lokalne zajednice kroz proces sustvaranja (Laven i dr., 2019) jest ono što čini jedan od temeljnih stupova definicije koncepta preoblikovanja mjesta. Holistički pristup, kao jedan od važnijih epiteta koji se pridaju konceptu preoblikovanja mjesta, odnosi se također dijelom na široku zastupljenost različitih društvenih skupina uključenih u proces planiranja, kao i na sveobuhvatnost u zahvaćanju društvenih i prostornih izazova (Ball, 2014) koji se stavljaju u fokus interesa. Richards $(2017 b, 2)$ ističe kako je riječ o „cjelovitoj društvenoj praksi koja uključuje fizičke promjene, kao i promjene u promišljanju i djelovanju". Pritom se, u
Placemaking, local community and tourism

Koncept preoblikovanja mjesta, lokalna zajednica i turizam 
postmodernism, the emphasis is on the process rather than the outcome or result (Sofield et al., 2017). Since the activities do not have a defined beginning, Platt and Medway (2020) advocate for positionality in the middle, i.e. acting upon the pre-existing foundations in the community and place and acknowledging the continuity of the process.

Placemaking can yield many benefits to the local community that are even more important than the ones to the place. These, foremost, refer to the increased quality of life, which will be discussed in greater detail in the next section. The benefits are primarily reflected in giving the voice to the local community (which could be a neighborhood, city, or region), strengthening it and giving their members the right to the space they use. In this regard, Balassiano and Maldonado $(2015,645)$ refer to placemaking as "visible evidence of the relationship between space and society." Through interventions and initiatives, the local community is engaged both individually and collectively, which contributes to creating an emotional connection with the place (Ghavampour and Vale, 2019).

In regard to the improved quality of place, placemaking involves planning, designing, and managing public spaces (Sofield et al., 2017) while thinking about the functionality, meaningfulness (Cilliers and Timmermans, 2014), and transformation of non-places, i.e. undistinguished, dilapidated, and unused spaces, into pleasant ones with amenities. It is worth mentioning that some authors (Kolås, 2004; Radney, 2019) do not think of placemaking in terms of all the aforementioned elements, but rather broadly consider it a physical and social occupation of space.

Other themes that some authors believe that define placemaking make up the last group. These include economic development due to placemaking, then its significance for marketing, and the roles of culture and art, particularly in the context of creative placemaking, which is considered a form of cultural policy in the United States.

Besides some isolated examples (e.g. Popović et al., 2016; Wise et al., 2019) in the Croatian scientific bibliography, the term placemaking is mostly used by ethnologists and cultural anthro- postmodernističkom duhu, ističe procesnost aktivnosti koje nemaju svoj konačni završetak ili rezultat (Sofield i dr., 2017) baš kao što nemaju ni u cijelosti definiran početak zbog čega Platt i Medway (2020) zagovaraju promišljanje koncepta preoblikovanja mjesta iz središnje pozicije, to jest djelovanje zasnovano na već postojećim temeljima u zajednici i prostoru, uz neophodno priznanje njegove beskonačnosti.

Važnija i od samoga djelovanja na prostor, u konceptu preoblikovanja mjesta jest dobrobit lokalne zajednice i povećana kvaliteta života, što se u prvom redu manifestira davanjem glasa stanovnicima nekoga područja (četvrti/grada/ regije) te njihovim osnaživanjem i polaganjem prava na prostor koji koriste. U tom kontekstu autori Balassiano i Maldonado koncept preoblikovanja mjesta nazivaju „vidljivim dokazom odnosa između društva i prostora" $(2015,645)$. Nizom intervencija i inicijativa potiče se kreativni individualni i kolektivni izričaj lokalnoga stanovništva te se doprinosi stvaranju emocionalne povezanosti s prostorom (Ghavampour i Vale, 2019).

Temeljne značajke koncepta preoblikovanja mjesta koje se odnose na izravno djelovanje na prostor tiču se poboljšanja kvalitete mjesta, pogotovo aktivnim korištenjem javnoga prostora planiranjem, dizajnom i upravljanjem (Sofield i dr., 2017), istodobno promišljajući smislenost i funkcionalnost (Cilliers i Timmermans, 2014) te transformirajući ne-mjesta, to jest neugledne, zapuštene i nekorištene prostore $\mathrm{u}$ prostore ugodne za boravak i ispunjene atraktivnim sadržajima. Vrijedna spomena jest i činjenica da pojedini autori (Kolås, 2004; Radney, 2019) pod pojmom preoblikovanja mjesta nužno ne podrazumijevaju sve ovdje navedene elemente, već njime označuju šire gledano, fizičko i socijalno zaposjedanje prostora od neke zajednice.

Posljednju skupinu koju čine ostale teme koje su pojedini autori istaknuli kao definirajuće za koncept preoblikovanja mjesta odnose se na ekonomski razvoj kao posljedicu intervencija preoblikovanja mjesta, zatim njegovu važnost u kontekstu marketinga te ulogu kulture i umjetnosti, osobito u kreativnom preoblikovanju mjesta, koje se u SAD-u smatra oblikom kulturne politike. 
pologists. They also use the Croatian translation of the term city-making, which would be stvaranje mjesta or stvaranje grada (Gulin Zrnić, 2004; Gulin Zrnić et al., 2016). Recurring themes include social practices of place production. Škrbić Alempijević and Oroz (2018) discussed ways of constructing the place of Hrvatsko zagorje through the perspectives of culture of memory related to Matija Gubec and Josip Broz Tito. Kelemen (2018) researched how the meaning of the city is constructed by migrants in Zagreb. Gulin Zrnić and Rubić (2018) analyzed the transformation of public spaces in the case of urban gardens. Selberg and Škrbić Alempijević (2013) discussed the construction of literary places. Kelemen and Škrbić Alempijević (2012) reflected on the effect festivals have on the identity and creation of a place. Gulin Zrnić (2004) analyzed the process of placemaking based on ethnographic research with children in the residential area of Novi $\mathrm{Za}^{-}$ greb. The topic of public space creation was dealt with both by the analysis of urban processes in the case of squares in Zagreb (Gulin Zrnić and Škrbić Alempijević, 2019), as well as by the project (and proceedings) The Place of Performance and City-making (Gulin Zrnić et al., eds., 2016). The focus of the project was on the research of artistic interventions in public spaces and the way citizens shape them.
Uz neke izdvojene primjere (npr. Popović i dr., 2016; Wise i dr., 2019) u hrvatskoj znanstvenoj bibliografiji pojam placemakinga ponajviše rabe etnolozi i kulturni antropolozi, koji se služe još i engleskim izrazom city-making, prevodeći ih na hrvatski jezik kao stvaranje mjesta, odnosno stvaranje grada (Gulin Zrnić, 2004; Gulin Zrnić i dr., 2016). Najčešće teme radova tiču se društvenih praksa proizvodnje prostora: autori Škrbić Alempijević i Oroz (2018) bave se načinima konstrukcije prostora Hrvatskog zagorja kroz perspektivu kulture sjećanja na Matiju Gupca i Josipa Broza Tita; Kelemen (2018) se bavi konstrukcijama značenja grada zagrebačkih migranata; Gulin Zrnić i Rubić (2018) analiziraju transformaciju javnih prostora na primjeru urbanih vrtova; Selberg i Škrbić Alempijević (2013) raspravljaju o konstrukciji književnih mjesta; Kelemen i Škrbić Alempijević (2012) bave se utjecajem festivalskih praksa na identitet $\mathrm{i}$ stvaranje mjesta; Gulin Zrnić (2004) analizira proces stvaranja mjesta na temelju etnografskoga istraživanja s djecom u jednom novozagrebačkom naselju. Problematika stvaranja javnih prostora posebno je obrađena $\mathrm{u}$ okviru analize urbanih procesa na primjeru zagrebačkih trgova (Gulin Zrnić i Škrbić Alempijević, 2019) te u sklopu projekta Mjesto izvedbe i stvaranje grada i istoimenoga zbornika (Gulin Zrnić i dr. (ur.), 2016) u kojem je fokus stavljen na istraživanje umjetničkih intervencija $u$ javnom prostoru te načina na koje stanovnici preoblikuju prostor grada.

Tab. 1 Scientific papers dealing with the definition of placemaking

Tab. 1. Znanstveni radovi na temu definicije koncepta preoblikovanja mjesta

\begin{tabular}{|c|c|c|}
\hline $\begin{array}{l}\text { GROUP } \\
\text { / SKUPINA }\end{array}$ & $\begin{array}{l}\text { THEME } \\
\text { /TEMA }\end{array}$ & $\begin{array}{l}\text { AUTHORS } \\
\text { / AUTORI }\end{array}$ \\
\hline \multirow{11}{*}{$\begin{array}{c}\text { NATURE OF THE CONCEPT } \\
\text { / PRIRODA KONCEPTA }\end{array}$} & \multirow{4}{*}{$\begin{array}{l}\text { Holistic practice } \\
\text { / Holistička praksa }\end{array}$} & Ball (2014); \\
\hline & & Duxbury and Richards (2019); \\
\hline & & Richards (2017b); \\
\hline & & Richards and Duif (2018) \\
\hline & \multirow{7}{*}{$\begin{array}{l}\text { Process } \\
\text { / Proces }\end{array}$} & Cilliers et al. (2015); \\
\hline & & Cilliers and Timmermans (2014); \\
\hline & & Laven et al. (2019); \\
\hline & & Platt and Medway (2020); \\
\hline & & Razali and Ismail (2014); \\
\hline & & Richards (2017b); \\
\hline & & Sofield et al. (2017) \\
\hline
\end{tabular}


HRVATSKI GEOGRAFSKI GLASNIK 83/1,77-104 (2021.)
Tab. 1 Scientific papers dealing with the definition of placemaking (continued)

Tab. 1. Znanstveni radovi na temu definicije koncepta preoblikovanja mjesta (nastavak)

\begin{tabular}{|c|c|c|}
\hline $\begin{array}{l}\text { GROUP } \\
\text { / SKUPINA }\end{array}$ & $\begin{array}{l}\text { THEME } \\
\text { /TEMA }\end{array}$ & $\begin{array}{l}\text { AUTHORS } \\
\text { / AUTORI }\end{array}$ \\
\hline \multirow{20}{*}{$\begin{array}{l}\text { NATURE OF THE CONCEPT } \\
\text { / PRIRODA KONCEPTA }\end{array}$} & \multirow{20}{*}{$\begin{array}{c}\text { Participatory planning } \\
\text { / Participativni pristup planiranju }\end{array}$} & Baka (2015); \\
\hline & & Cilliers and Timmermans (2014); \\
\hline & & Daniel and Kim (2020); \\
\hline & & Ellery and Ellery (2019); \\
\hline & & French (2018); \\
\hline & & Gallagher and Ehlman (2019); \\
\hline & & Ghavampour and Vale (2019); \\
\hline & & Laven et al. (2019); \\
\hline & & Marques and Richards (2014); \\
\hline & & Platt and Medway (2020); \\
\hline & & Razali and Ismail (2014); \\
\hline & & Razali et al. (2019); \\
\hline & & Redaelli (2016); \\
\hline & & Richards and Duif (2018); \\
\hline & & Sofield et al. (2017); \\
\hline & & Sutherland (2015); \\
\hline & & Thurlow and Jaworski (2014); \\
\hline & & Wilbur (2015); \\
\hline & & Wyckoff (2014); \\
\hline & & Zitcer $(2020)$ \\
\hline \multirow{30}{*}{$\begin{array}{l}\text { LOCAL COMMUNITY } \\
\text { / LOKALNA ZAJEDNICA }\end{array}$} & \multirow{19}{*}{$\begin{array}{l}\text { Local community development } \\
\text { and empowerment } \\
\text { / Razvoj i osnaživanje zajednice }\end{array}$} & Ball (2014); \\
\hline & & Balassiano and Maldonado (2015); \\
\hline & & Cilliers and Timmermans (2014); \\
\hline & & French (2018); \\
\hline & & Gadwa Nicodemus (2013); \\
\hline & & Galvis (2017); \\
\hline & & Ghavampour and Vale (2019); \\
\hline & & Kolås (2004); \\
\hline & & Lew (2017); \\
\hline & & Platt and Medway (2020); \\
\hline & & Radney (2019); \\
\hline & & Razali and Ismail (2014); \\
\hline & & Redaelli (2016); \\
\hline & & Richards (2017b); \\
\hline & & Shearmur (2018); \\
\hline & & Sofield et al. (2017); \\
\hline & & Vazquez (2012); \\
\hline & & Wilbur (2015); \\
\hline & & Wyckoff (2014) \\
\hline & \multirow{6}{*}{$\begin{array}{l}\text { Quality of life improvement } \\
\text { / Poboljšanje kvalitete života }\end{array}$} & Laven et al. (2019); \\
\hline & & Razali and Ismail (2014); \\
\hline & & Richards (2017b); \\
\hline & & Richards and Duif (2018); \\
\hline & & Sofield et al. (2017); \\
\hline & & Vazquez (2012) \\
\hline & \multirow{5}{*}{$\begin{array}{l}\text { Individual and collective expression } \\
\text { / Individualni i kolektivni izričaj }\end{array}$} & Balassiano and Maldonado (2015); \\
\hline & & Ball (2014); \\
\hline & & Ghavampour and Vale (2019); \\
\hline & & Lew (2017); \\
\hline & & Rosner-Manor et al. (2019) \\
\hline
\end{tabular}


Tab. I Scientific papers dealing with the definition of placemaking (continued)

Tab. 1. Znanstveni radovi na temu definicije koncepta preoblikovanja mjesta (nastavak)

\begin{tabular}{|c|c|c|}
\hline $\begin{array}{l}\text { GROUP } \\
\text { / SKUPINA }\end{array}$ & $\begin{array}{l}\text { THEME } \\
\text { /TEMA }\end{array}$ & $\begin{array}{l}\text { AUTHORS } \\
\text { / AUTORI }\end{array}$ \\
\hline \multirow{29}{*}{$\begin{array}{l}\text { PLACE } \\
\text { / PROSTOR }\end{array}$} & \multirow{5}{*}{$\begin{array}{l}\text { Quality of place improvement } \\
\text { / Poboljšanje kvalitete mjesta }\end{array}$} & Cilliers et al. (2015); \\
\hline & & Cilliers and Timmermans (2014); \\
\hline & & Razali et al. (2019); \\
\hline & & Richards and Duif (2018); \\
\hline & & Wyckoff (2014) \\
\hline & \multirow{11}{*}{$\begin{array}{l}\text { Public space interventions } \\
\text { / Intervencije u javnom prostoru }\end{array}$} & Ball (2014); \\
\hline & & Cilliers et al. (2015); \\
\hline & & Ellery and Ellery (2019); \\
\hline & & Gadwa Nicodemus (2013); \\
\hline & & Laven et al. (2019); \\
\hline & & Lew (2017); \\
\hline & & Razali et al. (2019); \\
\hline & & Richards (2017b); \\
\hline & & Sofield et al. (2017) \\
\hline & & Vazquez (2012); \\
\hline & & Wilbur (2015) \\
\hline & \multirow{8}{*}{$\begin{array}{l}\text { Liveable and meaningful } \\
\text { placemaking } \\
\text { / Stvaranje ugodnog i smislenog } \\
\text { prostora }\end{array}$} & Cilliers et al. (2015); \\
\hline & & Cilliers and Timmermans (2014); \\
\hline & & Dupre (2019); \\
\hline & & Ellery and Ellery (2019); \\
\hline & & Ghavampour and Vale (2019); \\
\hline & & Lew (2017); \\
\hline & & Razali et al. (2019); \\
\hline & & Wyckoff (2014) \\
\hline & \multirow{5}{*}{$\begin{array}{l}\text { Non-place transformation } \\
\text { / Transformacija ne-mjesta }\end{array}$} & Cilliers et al. (2015); \\
\hline & & Dupre (2019); \\
\hline & & Razali et al. (2019); \\
\hline & & Shearmur (2018); \\
\hline & & Sofield et al. (2017) \\
\hline \multirow{19}{*}{$\begin{array}{l}\text { OTHER } \\
\text { / OSTALO }\end{array}$} & \multirow{4}{*}{$\begin{array}{l}\text { Marketing tool } \\
\text { / Marketinški alat }\end{array}$} & Lew (2017); \\
\hline & & Razali and Ismail (2014); \\
\hline & & Shearmur (2018); \\
\hline & & Sofield et al. (2017) \\
\hline & \multirow{2}{*}{$\begin{array}{l}\text { Cultural policy } \\
\text { / Kulturna politika }\end{array}$} & Gallagher and Ehlman (2019); \\
\hline & & Zitcer (2020) \\
\hline & \multirow{6}{*}{$\begin{array}{l}\text { Economic development } \\
\text { / Ekonomski razvoj }\end{array}$} & French (2018); \\
\hline & & Laven et al. (2019); \\
\hline & & Lew (2017); \\
\hline & & Sofield et al. (2017); \\
\hline & & Vazquez (2012); \\
\hline & & Wyckoff (2014) \\
\hline & \multirow{7}{*}{$\begin{array}{l}\text { Culture and art } \\
\text { / Kultura i umjetnost }\end{array}$} & Daniel and Kim (2020); \\
\hline & & Redaelli (2016); \\
\hline & & Redaelli (2018); \\
\hline & & Rosner-Manor et al. (2019); \\
\hline & & Wilbur (2015); \\
\hline & & Wyckoff (2014); \\
\hline & & Zitcer $(2020)$ \\
\hline
\end{tabular}

I. Vodanović Lukić

Placemaking, local community and tourism

Koncept preoblikovanja mjesta, lokalna zajednica i turizam 


\section{Approaches to placemaking}

With respect to the local community's level of involvement in the process, there are two types of placemaking: organic and planned.

An organic approach to placemaking, also referred to as lived (Balassiano and Maldonado, 2015), indigenous (Zhao, 2019), and emic (Sofield et al., 2017) in academic literature, is a bottom-up approach which primarily responds to the needs of the local community (Cilliers and Timmermans, 2014), which is why it is considered more sustainable in the long run (Sofield et al., 2017). These are local initiatives that usually emerge spontaneously within the local community, without any help from the public or private sector with regard to design, implementation, and management (Sofield et al., 2017), and they carry an additional layer of symbolic appropriation of space for the local community (Balassiano and Maldonado, 2015). Zhao (2019, 599) argued that organic placemaking simultaneously creates and preserves "the local cultural soul."

On the other hand, planned or facilitated placemaking (Balassiano and Maldonado, 2015) refers to strategic top-down initiatives that are mostly controlled by those who are not the primary users of the space, and reflect the values of the social and political elites above the local level (Lew, 2017). Platt and Medway (2020) argue that planned placemaking is based on a hypothesis that place is largely shaped by organized interventions from outside the community. However, planned placemaking often does not consider local practices that reflect the everyday culture of a particular community.

From the perspective of tourism, the organic approach to placemaking creates unique places, and provides deep and meaningful experiences for tourists, who are not its primary focus group (Zhao, 2019). On the other hand, the planned approach is specifically aimed at meeting tourists' basic needs (Lew, 2017; Zhao, 2019) and results in a superficial (Zhao, 2019) and predictable (Lew, 2017) experience.

Organic and planned approaches to placemaking are ends on a continuum, and most places are a combination of both approaches, i.e. a mix of local

\section{Pristupi u preoblikovanju mjesta}

S obzirom na razinu uključenosti lokalne zajednice u proces preoblikovanja mjesta razlikujemo organski i planski pristup.

Organski pristup u preoblikovanju mjesta, koji se u literaturi još naziva življeni (Balassiano i Maldonado, 2015), autohtoni (Zhao, 2019) i emični (Sofield i dr., 2017) odnosi se na pristup odozdo prema gore koji primarno odgovara na potrebe lokalne zajednice (Cilliers i Timmermans, 2014), zbog čega se, dugotrajno gledajući, smatra održivijim (Sofield i dr., 2017). Riječ je o inicijativama lokalnoga karaktera koje najčešće nastaju spontano unutar lokalne zajednice, bez pomoći javnoga i privatnoga sektora u segmentu dizajna, implementacije i upravljanja (Sofield i dr., 2017), a za lokalnu zajednicu nose dodatni sloj simboličkoga prisvajanja prostora (Balassiano i Maldonado, 2015). Zhao $(2019,599)$ smatra kako organski oblik preoblikovanja mjesta istovremeno stvara i čuva „lokalnu kulturnu dušu”.

Planski ili potpomognuti pristup preoblikovanju mjesta (Balassiano i Maldonado, 2015) odnosi se pak na strateške inicijative odozgo prema dolje koje su najčešće pod nadzorom onih koji nisu primarni korisnici prostora te odražavaju vrijednosti društvene i političke elite iznad lokalne razine (Lew, 2017). Platt i Medway (2020) smatraju kako planski oblik preoblikovanja mjesta počiva na tezi prema kojoj se prostor u najvećoj mjeri oblikuje organiziranim intervencijama izvana, koje uz to najčešće nemaju dovoljno sluha za lokalne prakse koje odražavaju svakodnevnu kulturu zajednice.

Promatrajući iz perspektive turizma, organski pristup preoblikovanju mjesta stvara jedinstvene prostore, a turistima, unatoč tomu što nisu u prvotnom fokusu, pruža duboke i ispunjujuće doživljaje (Zhao, 2019). S druge strane, planski pristup ciljano je okrenut turistima, zadovoljavajući njihove uobičajene potrebe (Lew, 2017; Zhao, 2019) te rezultira površnim (Zhao, 2019) i predvidljivim (Lew, 2017) doživljajem.

Organski i planski pristup suprotni su polovi istoga kontinuuma, a većina naselja nalazi se između, kombinirajući istodobno jedan i drugi pristup, 
and global elements, which Lew (2017) considers the most suitable solution in the context of tourism. Smaller places, with a fewer number of visitors, tend to feature more characteristics of the organic approach, whereas a more planned approach is present in larger and more touristified places. Hultman and Hall (2012) concluded that a shift takes place in a destination over time. In the destinations shaped mostly by an organic approach, an increasing number of planned activities appeared, whereas in destinations previously saturated with planned activities, large number of local organic activities emerged.

Apart from the organic and planned approaches to placemaking, Wyckoff et al. (2015) noted additional four types of placemaking in their handbook on placemaking: standard; strategic; creative; and tactical. Standard placemaking refers to small-scale, day-to-day activities intended to improve quality of life and make a place more attractive; strategic placemaking is a process targeted at specific micro-locations and large-scale projects (such as cultural centers, museums, etc.); and tactical placemaking denotes temporary interventions in space that serve to test new concepts before more substantial investments. Even though these terms have a precise definition, their use in the rest of the consulted literature was not observed, the only exception being creative placemaking. Due to several highly-active organizations, as well as the popularity and attractiveness of the concept itself and its presence in research papers, creative placemaking is almost synonymous with the broader term of placemaking.

Creative placemaking refers to the urban practices and cultural policies that use cultural, artistic, and creative initiatives as tools for revitalization and means of improving quality of life (Vazquez, 2012; Redaelli, 2016; Gallagher and Ehlman, 2019; Daniel and Kim, 2020; Zitcer, 2020). The term emerged in the United States during the early years of the Obama administration and the recession (Zitcer, 2020) and has been widely used since the publication of a strategic document on creative placemaking authored by Markusen and Gadwa in 2010 (Markusen and Gadwa, 2010). Creative placemaking is characterized by a wide range of initiatives in the public to jest lokalne i globalne elemente, što u kontekstu turizma Lew (2017) smatra najpoželjnijim rješenjem. Uobičajeno, manja turistička mjesta, s nižim brojem posjetitelja, više pokazuju značajke organskoga pristupa, dok je u većim i turistificiranijim mjestima prisutniji planski pristup. Hultman i Hall (2012) zaključuju kako se tijekom vremena u destinaciji događa smjena pristupa, pri čemu se u destinacijama oblikovanim u najvećoj mjeri organskim pristupom sve više povećava broj planskih aktivnosti, dok se u destinacijama zasićenim planskim aktivnostima pojavljuju one lokalnoga, organskoga tipa.

Osim razlike između organskoga i planskoga pristupa preoblikovanju mjesta Wyckoff i dr. (2015) u priručniku posvećenu konceptu preoblikovanja mjesta razlikuju četiri tipa preoblikovanja mjesta: standardni, strateški, kreativni i taktički. Standardni oblik preoblikovanja mjesta odnosi se na svakodnevne aktivnosti poljepšavanja i poboljšavanja prostora u sitnijem mjerilu; strateški oblik preoblikovanja mjesta ciljani je proces usmjeren na točno određene mikrolokacije i projekte većega mjerila (npr. kulturni centri, muzeji); taktički oblik preoblikovanja odnosi se na privremene intervencije u prostoru kojima se testiraju novi koncepti prije velikih infrastrukturnih ulaganja. Unatoč precizno definiranim pojmovima u obrađenoj literaturi nije zabilježeno njihovo daljnje korištenje, izuzev pojma kreativnoga preoblikovanja mjesta, koji, zahvaljujući nizu vrlo aktivnih organizacija, kao i pristupačnosti i privlačnosti koncepta, po zastupljenosti u znanstvenim radovima gotovo postaje sinonim za univerzalni pojam preoblikovanja mjesta.

Kreativno preoblikovanje mjesta odnosi se na planerske prakse i kulturne politike koje uz pomoć kulture, umjetnosti i kreativnih inicijativa nastoje oko revitalizacije prostora i poboljšanja kvalitete života (Vazquez, 2012; Redaelli, 2016; Gallagher i Ehlman, 2019; Daniel i Kim, 2020; Zitcer, 2020). Početak upotrebe termina veže se za SAD i to period rane Obamine administracije i financijske krize (Zitcer, 2020), a ustalio se objavom strateškoga dokumenta autorica Markusen i Gadwa 2010. godine (Markusen i Gadwa, 2010). Odlikuje se širokim rasponom inicijativa u javnom prostoru (Gadwa Nicodemus, 2013), me-
Placemaking, local community and tourism

Koncept preoblikovanja mjesta, lokalna zajednica i turizam 
space (Gadwa Nicodemus, 2013), cross-sectoral partnerships (Gallagher and Ehlman, 2019), the involvement of different community voices (Gallagher and Ehlman, 2019; Daniel and Kim, 2020) and, above all, the active role of the artist, who creates together with the other local stakeholders (Zitcer, 2020). Apart from quality of life, this contributes to the creation of a collectively shared vision of space (street/neighborhood/town), social cohesion and inclusion (Redaelli, 2018), increased artistic and cultural activity on the part of the local community (Vazquez, 2012; Redaelli, 2016), and economic development (Zitcer, 2020). Just as with the broader term of placemaking, success is not measured by the number or size of completed structures dedicated to culture and arts, rather by how well the needs of the community are met thereby (Vazquez, 2012; Redaelli, 2016).

\section{Tools of placemaking}

Both planned and organic placemaking use the same tools for achieving their goals. In relation to the tangibility scale and within the context of tourism planning, and according to previous research, Lew (2017) grouped the tools into tangible, intangible, and mixed.

Tangible tools refer to physical design and include architecture, street furniture, greenery, open public spaces, particularly parks and city squares, and art in the public space. Research shows that participation in the urban design is closely related to creating a sense of belonging and strengthening the spatial and cultural identity of the community (Webb, 2014). O'Rourke and Baldwin (2016) reported an example of the inclusive participatory approach from an Australian university campus. With the help of a visual tool, the students were encouraged to think about key problems related to the facilities, use of campus space, and potential solutions to existing problems. The goal was to make the users feel more connected to the place. Artistic interventions aimed at repurposing a building with a controversial history in Berlin had the same goal. The suggestions of all participants, regardless of their expertise, were considered (Teder, 2019). Using the city acupuncture method, a survey was conducted in the city of Zagreb. The đusektorskom suradnjom (Gallagher i Ehlman, 2019), uključivanjem različitih lokalnih glasova (Gallagher i Ehlman, 2019; Daniel i Kim, 2020) te iznad svega aktivnom ulogom umjetnika, koji stvara u zajedništvu s drugim lokalnim dionicima (Zitcer, 2020). Osim već spomenutoj kvaliteti života, doprinosi stvaranju zajedničke vizije prostora (ulice/četvrti/grada), socijalnoj koheziji i inkluziji (Redaelli, 2018), povećanoj umjetničkoj i kulturnoj aktivnosti lokalnoga stanovništva (Vazquez, 2012; Redaelli, 2016) te ekonomskom razvoju (Zitcer, 2020). Baš kao i za šire shvaćeno preoblikovanje mjesta, uspjeh se ne mjeri brojem i veličinom izgrađenih objekata posvećenih kulturi i umjetnosti, nego kvalitetom odgovora na potrebe zajednice (Vazquez, 2012; Redaelli, 2016).

\section{Alati u preoblikovanju mjesta}

Planski i organski pristup u preoblikovanju mjesta koriste se istim alatima u postizanju svojih ciljeva. Na temelju prethodnih istraživanja, a s obzirom na razinu fizičke opipljivosti, Lew (2017) je u kontekstu turističkoga planiranja alate podijelio na materijalne, nematerijalne i mješovite.

Materijalni alati odnose se na dizajn urbanoga prostora te uključuju arhitekturu, urbani namještaj, zelene površine, otvorene javne prostore, osobito parkove i trgove te umjetnost u javnom prostoru. Brojni primjeri istraživanja pokazuju da je sudjelovanje u dizajnu urbanoga prostora usko povezano sa stvaranjem osjećaja pripadnosti te osnaživanjem prostornoga i kulturnoga identiteta zajednice (Webb, 2014). O'Rourke i Baldwin (2016) donose primjer inkluzivnoga participativnog pristupa u australskom sveučilišnom kampu, gdje se putem vizualnih alata nastojalo potaknuti studente na promišljanje o ključnim problemima vezanim za sadržaje i upotrebu prostora kampusa te njihovim potencijalnim rješenjima s ciljem ostvarivanja snažnijega osjećaja pripadnosti samih korisnika prostora. S jednakim ciljem organizirale su se i umjetničke intervencije u okviru osmišljavanja buduće namjene objekta kontroverzne povijesti u Berlinu, pri čemu su se prijedlozi svih sudionika, neovisno o njihovoj stručnoj pozadini uzeli na razmatranje (Teder, 
citizens were asked which initiatives, designed to improve quality of public spaces, had priority. The goal was to strengthen the ties between the citizens and their city (Careva et al., 2017). The same method with the same goal was applied in Brisbane (Houghton et al., 2015). Authors Brunnberg and Frigo (2012) explored how the feeling of belonging and a greater sense of community can be achieved through the use of a location-based mobile application that provides real-time insight into activities in public parks in Shanghai, thus promoting the use of public spaces. Placemaking in Stokes Croft, a small town in the United Kingdom, took the form of cultural activism, using various techniques (guerrilla signage, murals, graffiti, urban knitting, carnivalesque protests) to challenge the prevailing modes of urban development that were not focused on the local community (Buser et al., 2013). Street art, primarily murals have been responsible for the transformation of neglected and unattractive city districts in the post-industrial Polish city of Łódź (Mokras-Grabowska, 2014). In addition to beautifying dilapidated buildings left over from the industrialization period, murals have also influenced the perception of Eódź as a city of artistic and creative sensibility, which has resulted in greater recognition and increased tourist interest (Mokras-Grabowska, 2014; Jażdżews$\mathrm{ka}, 2017)$. Motivated individuals from the cultural, creative, and business sectors can have a significant role in placemaking as well (Vaništa Lazarević et al., 2016). They are capable of recognizing the potential of existing resources and engaging their community. The Savamala neighborhood in Belgrade is a good example of this. It was transformed from a dilapidated quarter with a bad reputation into an attractive bohemian-chic place that now attracts many visitors (Vaništa Lazarević et al., 2016). Due to the efforts of individuals and cultural initiatives the small Norwegian town of Vardø was transformed in a similar way (Haraldseid, 2019). The process was initiated by a group of community entrepreneurs who organized street art festivals, restored façades, and built new tourism infrastructure. Sparking citizens' interest in the cultural history of their own community by using a storytelling technique was key in initiating the overall revitalization.
2019). Uz pomoć metode akunpunkture grada istraživalo se mišljenje građana o prioritetnim inicijativama za poboljšanje kvalitete javnih prostora u gradu Zagrebu s ciljem jačanja osjećaja povezanosti (Careva i dr., 2017), a s jednakim se ciljem ista metoda koristila i u Brisbaneu (Houghton i dr., 2015). Autori Brunnberg i Frigo (2012) istraživali su kako se osjećaj pripadnosti i većega stupnja zajedništva među lokalnom zajednicom može postići korištenjem na lokaciji zasnovane mobilne aplikacije koja pruža uvid u trenutna zbivanja u javnim parkovima u Šangaju i time potiče upotrebu javnih prostora. Preoblikovanje mjesta na primjeru Stokes Crofta, malenoga gradića u Ujedinjenom Kraljevstvu, poprimilo je oblik kulturnoga aktivizma gdje se uz pomoć različitih tehnika (guerrilla signalizacija, murali, grafiti, urbano pletenje, karnevaleskni prosvjedi) propituju prevladavajući modeli urbanoga razvoja koji iz fokusa ispuštaju lokalnu zajednicu (Buser i dr., 2013). Ulična umjetnost zaslužna je za transformaciju zapuštenih i neuglednih gradskih četvrti u postindustrijskom poljskom gradu Łódźu (Mokras-Grabowska, 2014). Osim uljepšavanja derutnih građevina zaostalih iz perioda industrijalizacije, murali su utjecali i na stvaranje percepcije Eódźa kao grada umjetničkoga i kreativnoga senzibiliteta, što je rezultiralo i njegovom boljom prepoznatljivošću i povećanim turističkim interesom (Mokras-Grabowska, 2014; Jażdżewska, 2017). U transformaciji prostora značajnu ulogu ima angažman motiviranih pojedinaca iz kulturnoga, kreativnoga i poduzetničkoga sektora koji su sposobni prepoznati potencijal postojećih resursa te zajednicu potaknuti na djelovanje. Potvrđuje to primjer četvrti Savamala u Beogradu koja svoju transformaciju iz zapuštene četvrti sumnjive reputacije u atraktivan prostor boemskoga ozračja koji privlači posjetitelje može zahvaliti upravo pojedincima i kulturnim inicijativama (Vaništa Lazarević i dr., 2016). Sličnu transformaciju koju je pokrenulo okupljanje lokalnih poduzetnika doživio je i norveški gradić Vardø gdje se, uz projekte obnove pročelja, organizaciju festivala umjetničkoga karaktera te izgradnju nove turističke infrastrukture, za cjelokupnu revitalizaciju prostora ključnim pokazalo pobuđivanje interesa građana za kulturnu povijest vlastitoga grada, ponajviše korištenjem tehnika storytellinga (Haraldseid, 2019).
Placemaking, local community and tourism

Koncept preoblikovanja mjesta, lokalna zajednica i turizam 
Intangible tools of placemaking primarily refer to mental images and include different branding techniques that are based on storytelling, historical characters and events, myths, legends, as well as the creative and entertainment industries. Storytelling is particularly important in the context of tourism (Couret, 2019; Dodd, 2019), as we can see from the example of Canadian regions of Newfoundland and Labrador (Arsenault, 2019). Instead of applying the more traditional approach of merely selling tourist products, they built their brand through personal stories of their citizens, which has also strengthened the place identity (Cilliers and Timmermans, 2014). The identity of the Dutch city of 's-Hertogenbosch was also reinforced through storytelling (Richards, 2017a). Despite being the birthplace of the great medieval painter Hieronymus Bosch, not a single original artwork of Bosch's is in the city's possession. Nevertheless, 's-Hertogenbosch put itself on the global map by creatively using the painter's legacy to mark the $500^{\text {th }}$ anniversary of his death (Richards and Duif, 2018). It is important to point out that the many and varied social and cultural benefits that were derived from this were not the result of usual marketing strategies, rather of a more holistic approach to placemaking. While the former is focused on offering potential visitors the desired projected destination image, the latter deals with creating meaning for the local community (Kavaratzis and Ashworth, 2005; Jelinčić et al., 2017; Duxbury and Richards, 2019). Creative industries also play a role in shaping the identity of a place, as the research by Durmaz et al. (2010) on moving the film industry to the city center of London and Istanbul showed. It had a double positive effect. First, it contributed to the creativity of the industry itself and, second, it positively affected the image of the place and drove economic and spatial development. The case of Mount Airy, a town in South Carolina, is another example of how the creative industries can influence the image of a place. It owes its popularity to the fact it probably served as the inspiration for a fictional city (called Mayberry) that a popular television show was based on (Alderman et al., 2012). Mount Airy thus created its image by using different practices, primarily renaming places, organizing festivals, building place
Nematerijalni alati u preoblikovanju mjesta odnose se primarno na mentalne slike te uključuju različite tehnike brendiranja koje počivaju na storytellingu, povijesnim ličnostima i događajima, mitovima i legendama, kao i kreativnoj i zabavnoj industriji. Storytelling je osobito važan u kontekstu turizma (Couret, 2019; Dodd, 2019), što pokazuje i primjer kanadskih regija Newfoundland i Labrador (Arsenault, 2019), koje su se umjesto klasične prodaje turističkih proizvoda odlučile na brendiranje kroz osobne priče svojih stanovnika, osnažujući tako identitet prostora (Cilliers i Timmermans, 2014). Na prostorni identitet upotrebom tehnike storytellinga nastojalo se utjecati i u nizozemskom gradu ,s-Hertogenboschu, rodnom gradu velikoga srednjovjekovnog slikara Hieronymusa Boscha (Richards, 2017a). Unatoč činjenici da se u gradskom vlasništvu ne nalazi nijedno Boschovo originalno djelo, ali oslanjajući se na kreativnu interpretaciju njegova stvaralaštva u sklopu programa obilježavanja 500-te obljetnice smrti, ,s-Hertogenbosch je uspješno povezao umjetnika s gradom, zadobivši pritom globalnu prepoznatljivost (Richards i Duif, 2018). Važno je naglasiti kako različite i brojne društvene i kulturne dobrobiti koje su iz toga proizašle nisu rezultat uobičajenih marketinških koraka, koji su u prvom redu okrenuti projekciji željenoga imidža destinacije potencijalnim posjetiteljima, već upravo holističkoga procesa preoblikovanja mjesta, koji u obzir uzima stvaranje značenja za samu lokalnu zajednicu (Kavaratzis i Ashworth, 2005; Jelinčić i dr., 2017; Duxbury i Richards, 2019). Ulogu u oblikovanju prostornoga identiteta imaju i kreativne industrije, što pokazuje i istraživanje Durmaz i dr. (2010) na primjeru filmske industrije u Istanbulu i Londonu čijim se smještanjem u gradsko središte polučuje dvostruk pozitivni učinak: $s$ jedne strane doprinosi se kreativnosti same industrije, a s druge pozitivno utječe na imidž prostora, a time i na njegov daljnji ekonomski i prostorni razvoj. Primjer utjecaja kreativnih industrija na imidž prostora jest i slučaj Mount Airyja, gradića u Sjevernoj Karolini, koji svoju popularnost duguje popularnoj televizijskoj seriji za koju je vjerojatno poslužio kao predložak (Alderman i dr., 2012). Služeći se različitim praksama, poglavito preimenovanja pojedinih lokacija, organizacije festivala, izgradnje replika i uprizorenja likova i radnji iz TV serije u gradskom prostoru, Mount Airy imidž 
replicas, and re-enacting characters and plot with the aim of associating its image with its fictional counterpart.

Mixed tools, a combination of tangible and intangible elements, mostly refer to the organization of festivals and various events, formal and informal entertainment, street life, food and drinks, and other social practices. The analysis of the available literature has shown that the most-used mixed tool is the organization of festivals and various events intended to meet the needs of the local community. The ability of events to affect a broad range of changes makes them an attractive placemaking tool (Barrera-Fernández and Hernández-Escampa, 2017; de Britto and Richards, 2017). It has been reported that events are a stimulus for economic growth, cultural development, social cohesion (Brownett and Evans, 2020), creation of a positive image (Barrera-Fernández and Hernández-Escampa, 2017; Richards and Duif, 2018), and urban regeneration (de Britto and Richards, 2017). Apart from the wider social and economic significance, festivals also play an important role in destination differentiation, particularly between destinations that have similar offerings. However, to achieve this, festivals must be embedded in the destination's culture (Sol et al., 2017), be able to connect the local community with the place (Coghlan et al., 2017), and reflect a sense of place (Derett, 2003). Numerous examples cited in the literature corroborate the benefits of festivals, events, and other practices known as mixed tools of placemaking. The aforementioned Dutch city of 's-Hertogenbosch also used cultural programming for various types of events aimed at bringing about long-term changes, attracting tourists, as well as reconnecting and supporting networking between the citizens (Richards and Duif, 2018). The unconventional art initiative in Turin called Paratissima grew out of protest against the established contemporary art fair Artissima and its way of promoting artists (Rota and Salone, 2014). Paratissima has become a place where various social groups meet due to its democratic practices. The artists exhibit their work at the unusual and atypical places such as street or private venue. Also, anyone can exhibit their work if they can temelji na svom fiktivnom pandanu, gradiću Mayberryu, nastojeći utjeloviti pozitivne konotacije koje televizijska publika za njega veže.

Mješoviti alati, koji kombiniraju materijalne i nematerijalne elemente, najčešće se odnose na organizaciju festivala i različitih događanja, formalnu i neformalnu zabavu, ulični život, hranu i piće te ostale društvene prakse. Analizom dostupne literature primijećeno je da se najčešće korišteni mješoviti alati odnosi na organizaciju festivala i različitih događanja kojima je temeljna zadaća odgovoriti na različite potrebe lokalne zajednice. Atraktivnost događanja kao alata u preoblikovanju mjesta proizlazi iz njegove sposobnosti utjecaja na širok raspon promjena (Barrera-Fernández i Hernández-Escampa, 2017; de Britto i Richards, 2017). Tako se u literaturi navodi kako su događanja stimulans za ekonomski rast, kulturni razvoj i socijalnu koheziju (Brownett i Evans, 2020), stvaranje pozitivnoga imidža (Barrera-Fernández i Hernández-Escampa, 2017; Richards i Duif, 2018) i urbanu regeneraciju (de Britto i Richards, 2017). Osim šire društvene i ekonomske važnosti, festivali imaju bitnu ulogu u diferencijaciji destinacija, osobito onih slične atrakcijske osnove, no da bi to ostvarili, moraju biti umreženi s kulturnom ponudom u destinaciji (Sol i dr., 2017), upućivati na jasnu povezanost lokalne zajednice i prostora (Coghlan i dr., 2017) te odražavati osjećaj mjesta (Derrett, 2003). Brojni primjeri u literaturi potkrjepljuju navedene dobrobiti festivala, događanja i drugih praksa koje smatramo mješovitim alatima u preoblikovanju mjesta. Već spomenuti primjer nizozemskoga grada ,s-Hertogeneboscha u programiranju svojih kulturnih aktivnosti uvelike se oslanjao na različite tipove događanja kojima je cilj, osim stimulacije dugoročnijih promjena i privlačenja turista, bilo i povezivanje i umrežavanje samih građana ( $\mathrm{Ri}$ chards i Duif, 2018). Nekonvencionalna umjetnička inicijativa u Torinu Paratissima nastala je kao svojevrsni prosvjed protiv etablirane izložbe suvremene umjetnosti Artissima i njezina načina promocije umjetnika (Rota i Salone, 2014). Zahvaljujući svojoj demokratičnosti u izboru izložbenoga prostora, koji najčešće uključuje atipične, ulične i privatne ambijente te u mogućnostima izlaganja koje je otvoreno za sve koji su spremni platiti simboličnu naknadu, Paratissima je postala mjesto susreta različitih druš-
Placemaking, local community and tourism

Koncept preoblikovanja mjesta, lokalna zajednica i turizam 
pay a small fee. The fair has contributed to social cohesion and building of the identity of the San Salvario neighborhood where it takes place. Various events and art activities organized by the community organization IMAN (Inner-City Muslim Action Network) in Chicago (Ali, 2017) also have a distinct social dimension. The organization's aim is to increase the quality of life for the local community's rather than to attract the creative class (Lew, 2017). They do it by activating the social and cultural capital of marginalized social groups (Ali, 2017). Gilbert et al. (2018) also addressed vernacular creativity and the need for it to be more included in placemaking (Markusen, 2014) in the context of creative practices such as festivals, transformation of spaces for religious worship, and various group activities followed by the faith communities in London. Platt (2017) also emphasized the importance of vernacular creativity. She gave the example of women's knitting groups in Liverpool and their activities, like yarn bombing, that they use to decorate public spaces. Vernacular creativity is becoming an important part of formal placemaking due to its appeal. However, stakeholders often disapprove of it because of the lack of an integral political or social message, and the fact that it is reduced to mere decorative purposes. The creative initiatives in Christchurch, New Zealand after the big earthquakes in 2010 and 2011 are particularly interesting. Maidment et al. (2019) called them therapeutic placemaking. Groups of women spontaneously gathered and crocheted, knitted, and sewed which helped create a sense of safety and stability amid the overall atmosphere of chaos and depression. The handicrafts were a form of outlet for their own emotions, as well as the emotions of their fellow citizens. They were placed mostly in easily visible places or used to decorate the destroyed landmarks of their city. There are also numerous examples of local communities' active engagement with the organization of various events that resulted in a larger number of tourists. Unsatisfied with the way the big tour operators managed the tourism supply, the inhabitants of a village of Arillas on the island of Corfu in Greece decided to take matters into their own hands by organizing a range of events, which attracted recurring visitors, precisely because of their tvenih skupina, doprinijevši tako socijalnoj koheziji i izgradnji identiteta četvrti San Salvario u kojoj se održava. Izraženu socijalnu dimenziju imaju i različita događanja i umjetničke aktivnosti u organizaciji lokalne udruge IMAN (Inner-City Muslim Action Network) u Chicagu (Ali, 2017) kojoj je cilj, umjesto privlačenja kreativne klase, aktivirati socijalni i kulturni kapital marginaliziranih društvenih skupina i na taj način doprinijeti kvaliteti života lokalne zajednice (Lew, 2017). O vernakularnoj ili amaterskoj kreativnosti i potrebi za njezinom snažnijom inkluzijom u procese preoblikovanja mjesta (Markusen, 2014) progovaraju Gilbert i dr. (2018) u kontekstu različitih kreativnih praksa (festivali, uljepšavanje obrednih prostora, različite zajedničke aktivnosti) religijskih zajednica u Londonu. Važnost vernakularne kreativnosti, koja zbog svoje atraktivnosti sve češće postaje važan dio formalnoga preoblikovanja mjesta (unatoč nerijetkom negodovanju njezinih dionika zbog izostanka integralne političke ili socijalne poruke i svođenja na puku dekorativnost), ističe i Platt (2017) na primjeru ženskih grupa za pletenje u Liverpoolu i njihovih aktivnosti ukrašavanja javnoga prostora pletenim/ heklanim kreacijama. Osobito su zanimljivi primjeri kreativnih inicijativa u gradu Christchurch u Novom Zelandu nakon velikih potresa 2010. i 2011. godine koje su autori prozvali terapeutskim preoblikovanjem mjesta ( $\mathrm{Ma}-$ idment i dr., 2019). Riječ je ponajviše o spontanim okupljanjima žena oko aktivnosti kao što su zajedničko heklanje, pletenje i šivanje čime su, u sveopćoj atmosferi kaosa i depresije, nastojale stvoriti prostor sigurnosti i stabilnosti. Svoje osjećaje, kao i osjećaje svojih sugrađana materijalizirale su kroz rukotvorine, postavljajući ih često na uočljiva mjesta ili njima ukrašavajući razrušene poznate građevine svoga grada. Brojni su i primjeri aktivnoga angažmana lokalnih zajednica oko organizacije različitih događanja s ciljem ostvarenja boljih turističkih rezultata. Nezadovoljni načinom na koji su veliki turoperatori utjecali na turističko upravljanje destinacijom, mještani maloga naselja Arillas na otoku Krfu u Grčkoj odlučili su sami organizirati svoju turističku ponu$\mathrm{du}$, što je rezultiralo nizom aktivnosti, među kojima se isticalo i nekoliko događanja lokalnoga karaktera, koja su upravo takvim formatom uspjela privući stalne posjetitelje (Christou, 2017). Slične inicijative pokrenute su i u povijesnom gradiću Evandale u Ta- 
local character (Christou, 2017). Concerned that the town was losing its identity and ability to attract visitors, the local community of the historical town of Evandale in Tasmania started a new festival featuring a penny farthing race, as well as other activities (Sofield et al., 2017).

\section{The local community and place within placemaking}

Initiatives, such as placemaking (particularly creative placemaking), which have the goal of improving the local community's quality of life in a sustainable way, are only successful if the local community plays an active role (Lefebvre, 1991; Friedmann, 2010; Cilliers and Timmermans, 2014; Śmid Hribar et al., 2015; Frangos et al., 2017; Dupre, 2019; Gallagher and Ehlman, 2019). However, in modern, seemingly participatory spatial and urban planning, we often witness mere tokenistic participation (Cilliers and Timmermans, 2014; Franklin and Marsden, 2015). By actively engaging the local population, the place can be developed in line with the local culture and the needs of the local community (Razali and Ismail, 2014), while at the same time the community can equally utilize and benefit from their own territorial capital on equal terms with tourists. Territorial capital here refers both to natural resources and cultural values of a place (Šmid Hribar et al., 2015).

The value that the place has for the local population was described by Cilliers and Timmermans (2014), who highlighted the fact that place and architecture are much more than background factors. On the contrary, they are interwoven with personal stories and strongly affected by the bond with the immediate and wider community, which particularly stands out in festivals and cultural events (Wynn and Yetis-Bayraktar, 2016). This further reaffirms the importance of involving the local population in the creation of place.

One of the fundamental features of quality placemaking is the development of the sense of belonging (Kelkar and Spinelli, 2016) which is based on each individual or community's basic need to participate in civic life, i.e. in making decisions which affect their lives. (Cilliers and Timmermans, 2014). smaniji, gdje je zabrinutost oko gubitka vlastitoga identiteta i smanjena broja posjetitelja potaknula lokalnu zajednicu na osmišljavanje novoga festivala u sklopu kojega se, uz brojna popratna događanja, odvija i atraktivna utrka penny farthing biciklima (Sofield i dr., 2017).

\section{Lokalna zajednica i prostor unutar koncepta preoblikovanja mjesta}

Ključ uspjeha inicijativa kojima je cilj poboljšanje kvalitete života lokalne zajednice na održiv način, kao što je to koncept preoblikovanja mjesta, osobito kreativnoga, jest u dodjeljivanju aktivne uloge lokalnom stanovništvu (Lefebvre, 1991; Friedmann, 2010; Cilliers i Timmermans, 2014; Šmid Hribar i dr., 2015; Frangos i dr., 2017; Dupre, 2019; Gallagher i Ehlman, 2019), za razliku od tokenističke uključenosti, često prisutne u suvremenom, naizgled participativnom planiranju prostora (Cilliers i Timmermans, 2014; Franklin i Marsden, 2015). Aktivnim sudjelovanjem lokalnoga stanovništva potiče se razvoj prostora koji je u skladu s lokalnom kulturom i potrebama (Razali i Ismail, 2014) te se istodobno lokalnoj zajednici omogućuje ravnopravno korištenje i uživanje (zajedno s turistima) u vlastitom teritorijalnom kapitalu, koji se, uz prirodne resurse, odnosi i na kulturne vrijednosti prostora (Šmid Hribar i dr., 2015).

Značenje koje prostor ima za lokalne stanovnike, što ujedno i potvrđuje neophodnost njihova uključivanja u kreiranje toga prostora, opisali su Cilliers i Timmermans (2014) istaknuvši kako su prostor i arhitektura puno više od kulisa s obzirom na to da su u njih utkane osobne povijesti sačinjene od odnosa s užom i širom zajednicom, što ponajviše dolazi do izražaja u kontekstu festivala i kulturnih događanja (Wynn i Yetis-Bayraktar, 2016). To dodatno potvrđuje važnost uključivanja lokalnog stanovništva u preoblikovanje mjesta.

Razvoj osjećaja pripadnosti jedna je od temeljnih oznaka kvalitetnoga preoblikovanja mjesta (Kelkar i Spinelli, 2016) koja počiva na osnovnoj potrebi pojedinca ili zajednice za sudjelovanjem u građanskom životu, to jest u donošenju odluka koje imaju izravan utjecaj na njihove živote (Cilliers i
Placemaking, local community and tourism

Koncept preoblikovanja mjesta, lokalna zajednica i turizam 
One of the most important objectives of placemaking is to encourage the local community to take responsibility for spatial processes and regain control over its surroundings (Cilliers and Timmermans, 2014; Kelkar and Spinelli, 2016), which is achieved solely by getting involved on a personal level and by investing time and energy (Cilliers and Timmermans, 2014; Sofield et al., 2017). Being able to leave an impact and take control transforms "passive users of services and spaces to designers and producers" (Kelkar and Spinelli, 2016, 57). There is, thus, a shift from indifference to mindfulness (Moscardo, 1996). The higher the level of local community's involvement in placemaking is, the stronger the community's sense of place will be (Lew, 2017; Ellery and Ellery, 2019). Sense of place can be described as belonging to and feeling a connection with a physical space (Cresswell, 2004), primarily due to the personal and collective identity that develops from that connection (Butterworth, 2000). Through placemaking people engage with the place, which also empowers the local community (Kelkar and Spinelli, 2016; Murdoch III et al., 2016) for future actions aimed at achieving common interests. This is particularly notable in rural, smaller, or less-developed communities (Ellery and Ellery, 2019). Using Arnstein's ladder of citizen participation, Ellery and Ellery (2019) explained that the higher the level on the ladder (which also suggests a higher level of participation and independence on the part of the local community), the stronger the sense of place and sense of community will be.

In addition, because placemaking fosters social interaction (Kelkar and Spinelli, 2016; Dupre, 2019), the direct outcome is the construction of social capital and social cohesion of the local community (Brunnberg and Frigo, 2012; Cilliers and Timmermans, 2014; Kelkar and Spinelli, 2016). Public space plays a key role in this (PPS, 2009; PPS, 2012; Richards and Duif, 2018; Laven et al., 2019). Public space shapes a city's identity, and its quality is determined by the quantity of content that fosters interaction (Cilliers and Timmermans, 2014), as well as the degree of control that the community has when it comes to shaping the place (Cilliers et al., 2015). Placemaking, as a form of creating quality public spaces, empowers the
Timmermans, 2014). Jedan od najvažnijih ciljeva preoblikovanja mjesta sastoji se u poticanju lokalne zajednice da preuzme odgovornost za prostorne procese i kontrolu nad vlastitim okruženjem ( $\mathrm{Ci}-$ 1liers i Timmermans, 2014; Kelkar i Spinelli, 2016), što se postiže isključivo osobnim angažmanom i ulaganjem vlastitoga vremena i energije (Cilliers i Timmermans, 2014; Sofield i dr., 2017). Mogućnost utjecaja i kontrole preobražava pasivnoga korisnika prostora u „dizajnera prostora” (Kelkar i Spinelli, 2016, 57), pri čemu se iz stanja nezainteresiranosti prelazi u stanje osviještenosti (engl. mindfulness) (Moscardo, 1996). Razmjerno razini uključenosti lokalne zajednice u procese oblikovanja prostora poveća se i osjećaj mjesta (engl. sense of place) (Lew, 2017; Ellery i Ellery, 2019), što se odnosi na pripadnost i povezanost s fizičkim prostorom (Cresswell, 2004), ponajviše osobnim i kolektivnim identitetom koji iz te povezanosti proizlazi (Butterworth, 2000). Praksa preoblikovanja mjesta potiče povezivanje ljudi s prostorom, što je bitno $s$ gledišta osnaživanja lokalne zajednice (Kelkar i Spinelli, 2016; Murdoch III i dr., 2016) za buduća djelovanja s ciljem ostvarivanja zajedničkih interesa, posebno u ruralnim, manjim ili slabije razvijenim zajednicama (Ellery i Ellery, 2019). Služeći se Arnsteinovim ljestvama sudjelovanja, autori Ellery i Ellery (2019) navode da više mjesto na ljestvama u praksi preoblikovanja mjesta (što podrazumijeva veći angažman i samostalnost lokalne zajednice) jamči i veći osjećaj mjesta i s njim povezan osjećaj zajednice.

Osim toga, izravan utjecaj preoblikovanja mjesta kao odraz pojačanih socijalnih interakcija (Kelkar i Spinelli, 2016; Dupre, 2019) ogleda se u povećanju socijalnoga kapitala te socijalne kohezije lokalne zajednice (Brunnberg i Frigo, 2012; Cilliers i Timmermans, 2014; Kelkar i Spinelli, 2016) u čemu ključnu ulogu ima javni prostor (PPS, 2009; PPS, 2012; Richards i Duif, 2018; Laven i dr., 2019). Javni prostor oblikuje identitet grada, a njegova kvaliteta određena je količinom sadržaja koji potiču interakciju (Cilliers i Timmermans, 2014) kao i stupnjem kontrole koji zajednica posjeduje kad je u pitanju njegovo oblikovanje (Cilliers i dr., 2015). Činom preoblikovanja mjesta koji je određen stvaranjem kvalitetnih javnih prostora osnažuje 
community and establishes a stronger connection with the place (PPS, 2009). The best results, both sustainable and strategic, are achieved by including as many and as diverse local stakeholders as possible (Cilliers and Timmermans, 2014; Franklin and Marsden, 2015) and by partnering with other sectors and across disciplines (Dupre, 2019; Gallagher and Ehlman, 2019).

While some authors favor the organic approach to placemaking, i.e. giving the local community complete freedom to plan their place (Sofield et al., 2017), others are more in favor of the mixed approach, which equally engages local stakeholders and experts from different fields in planning the space (Friedmann, 2010; Cilliers and Timmermans, 2014; Franklin and Marsden, 2015; Lew, 2017; Gallagher and Ehlman, 2019). One such example would be the development of $\mathrm{cu}^{-}$ linary tourism in less-developed Danish destinations with the help of the triple helix model of innovation, which is based on cooperation between the economic sector, research institutions, and political actors (Sundbo and Sundbo, 2019). In both cases, civil organizations and initiatives act as middlemen with the role of bringing members of the local community together to solve problems (Kelkar and Spinelli, 2016). Often, artists are engaged in the process as well (Daniel and Kim, 2020). Recently, the role of tourists in the design of the place has become increasingly important (Razali et al., 2019), especially in connection with creative tourism that involves both tourists and hosts in the process of co-creation (Richards, 2018; Couret, 2019). Even then, the local community should have the last word when it comes to their right to the space. Mansfeld (2019) suggested the use of the concept of relative sustainability, based on the expectations and limitations of the local population, unlike the standard concepts of sustainability that are less sensitive to the specific local context.

Within the context of placemaking, a place and its connection with the local community can be viewed in its multiplicity with the help of Lefebvre's trialectics of spatiality (Lefebvre, 1991). Lefebvre outlined three kinds of space: perceived space or physical space; conceived space or representations se zajednica te se uspostavlja njezina čvršća veza s prostorom (PPS, 2009). Pritom se najbolji rezultati, s predznakom održivosti i strateškoga promišljanja prostora, postižu uključivanjem što većega broja različitih lokalnih dionika (Cilliers i Timmermans, 2014; Franklin i Marsden, 2015) te međusektorskom suradnjom i multidisciplinarnošću (Dupre, 2019; Gallagher i Ehlman, 2019).

Dok neki autori najboljim pristupom smatraju organski vid preoblikovanja mjesta, to jest prepuštanje planiranja prostora u cijelosti lokalnoj zajednici (Sofield i dr., 2017), drugi su pak skloniji primjerima nastalim kao rezultat mješovitoga pristupa, odnosno podjednakim angažmanom lokalnih dionika i stručnjaka iz različitih disciplina (Friedmann, 2010; Cilliers i Timmermans, 2014; Franklin i Marsden, 2015; Lew, 2017; Gallagher i Ehlman, 2019). Slučaj je to, primjerice, s razvojem gastronomskoga turizma u slabije razvijenim danskim destinacijama korištenjem modela triple helix, pri čemu međusobno surađuju gospodarski sektor, istraživačke institucije te politički akteri (Sundbo i Sundbo, 2019). U oba slučaja važna, gotovo posrednička uloga pripada građanskim udrugama i inicijativama koje međusobno povezuju pripadnike lokalne zajednice, često i uz angažman umjetnika (Daniel i Kim, 2020), sa svrhom zajedničkoga rješavanja problema (Kelkar i Spinelli, 2016). Posljednjih godina sve se više priznaje i važnost turista u oblikovanju prostora turističkih destinacija (Razali i dr., 2019), osobito u kontekstu kreativnoga turizma u sklopu kojega su turisti, zajedno sa svojim domaćinima, uključeni u proces sustvaranja (Richards, 2018; Couret, 2019). No, i u tom slučaju posljednju riječ uvijek bi trebala imati lokalna zajednica koja polaže veće pravo na prostor upravo njegovim kontinuiranim korištenjem zbog čega Mansfeld (2019) sugerira primjenu koncepta relativne održivosti, koja bi se, za razliku od standardiziranih koncepata održivosti koji su manje osjetljivi na specifične lokalne uvjete, temeljila upravo na očekivanjima i ograničenjima lokalnih stanovnika.

U procesu preoblikovanja mjesta poželjno je prostor i vezu s lokalnom zajednicom sagledati u njegovoj višestrukosti, na tragu Lefebvrove trijalektike prostora (Lefebvre, 1991), prema čemu prostor osim njegove fizičke stvarnosti čine i mentalne predodžbe (reprezentacije prostora) koje najčešće
Placemaking, local community and tourism

Koncept preoblikovanja mjesta, lokalna zajednica i turizam 
GEOGRAFSKI

GLASNIK

83/1,77-104 (2021.) of space mostly created by politicians, planners, and designers (mental images); and lived space used by people in everyday life (spaces of representation). Richards (2017b; Richards and Duif, 2018) viewed Lefebvre's three dimensions of space in the process of placemaking as resources (physical space), meanings (representations of space), and creativity (lived space). It is the city's task "to bring resources together in new creative ways to give them new meanings" (Richards and Duif, 2018,59), while ensuring better quality of life for the local population and meeting tourists' needs. While planning, it is key to take all three spatial dimensions into consideration and find a balance between them (Richards and Duif, 2018). Otherwise, placing too much emphasis on the resources could result in serial reproduction, whereas relying too much on building a brand name and marketing it without being realistic would mean overemphasizing the meaning. On the other hand, too much emphasis on creativity could lead to elitism and superficiality.

It is easy to fall into the "trap of creativity" (Richards, 2019, 7) when following the existing development models if one does not make the necessary adjustments to the local context and needs. Despite emphasizing the importance of the human factor in shaping creative urban dynamics and new spatial patterns, for which they are credited, the critique largely refers to the creative strategies of Charles Landry and Richard Florida. Richard Florida's theory of creative class popularized the creative city model (Kelly et al., 2017), which is centered on the idea that art has an economic role, particularly in the form of commercial products (Murdoch III et al., 2016). Florida (2002) claimed that creative class was a driving force behind regional economic development. However, Murdoch III et al. (2016) listed numerous downsides to this approach such as putting economic benefits before the benefits of the local community. Their research regarding artistic and cultural organizations in New York neighborhoods showed that most of those organizations worked as a magnet for the wealthier, the creative class, and tourists, while a smaller number of organizations, with lower budgets located in low-income neighborhoods, were focused on developing the local community. kreiraju političari, planeri i dizajneri te življeni prostor, to jest onaj koji nastaje kao rezultat svakodnevnoga korištenja od ljudi koji ga nastanjuju (prostori reprezentacije). Lefebvrove tri dimenzije prostora u kontekstu praksi preoblikovanja mjesta Richards (2017b; Richards i Duif, 2018) promatra kao resurse (fizički prostor), značenja (reprezentacije prostora) i kreativnost (življeni prostor) pri čemu je zadatak gradova da „vlastite resurse osmisle na kreativne načine kako bi im dali nova značenja” (Richards i Duif, 2018, 59) te na taj način istodobno osiguraju višu razinu kvalitete življenja lokalnoga stanovništva, kao i zanimanje turista. Pritom je ključno prilikom planiranja uzeti u obzir sve tri prostorne razine te raditi na uspostavi ravnoteže između njih (Richards i Duif, 2018), u protivnom, dolazi do serijske reprodukcije (naglasak na resursima), pretjerana oslanjanja na brendiranje i marketing mjesta bez podloge u stvarnosti grada (naglasak na značenja) te elitizma i površnosti (naglasak na kreativnosti).

U „zamku kreativnosti” (Richards, 2019, 7) upada se, prema Richardsu, slijedeći postojeće modele razvoja bez neophodnih prilagodba lokalnim uvjetima i potrebama. Unatoč isticanju važnosti ljudskoga čimbenika u stvaranju kreativne urbane dinamike i novih prostornih obrazaca za koje se smatraju zaslužnima, kritika se u velikoj mjeri odnosi na kreativne razvojne strategije Charlesa Landryja i Richarda Floride. Model kreativnoga grada, koji je popularizirala teorija Richarda Floride o kreativnoj klasi (Kelly i dr., 2017) kao ključnoj za regionalni ekonomski razvoj (Florida, 2002), počiva na ekonomskoj ulozi umjetnosti, osobito u obliku sadržaja potrošačkoga karaktera (Murdoch III i dr., 2016). Murdoch III i dr. (2016) navode brojne nedostatke ovoga pristupa, a zajedničko im je stavljanje ekonomske dobiti ispred dobrobiti lokalne zajednice. Njihovo istraživanje o umjetničkim i kulturnim organizacijama u četvrtima New Yorka pokazalo je da većina takvih organizacija funkcionira kao magnet za imućniju, kreativnu klasu i turiste, dok je tek manji broj, i to onih s nižim budžetom te smještenih u siromašnijim četvrtima, okrenut razvoju lokalne zajednice. 
Instead of the prescriptive models of creativity that rely exclusively on the creative sector, numerous authors argue that creativity should be a holistic practice (Richards, 2019). Everyday creativity (Ghavampour and Vale, 2019) that is embedded in the local lifestyles, ways of spending free time, and local artistic expressions ranging from literature, music to visual arts, play a key role (Richards, 2017b). The quality of life of the local community can be improved through cooperation and partnership, and realizing the full potential already present in the community (Frenette, 2017), instead of searching for outside talent (Ghavampour and Vale, 2019) or exclusively relying on experts (Razali et al., 2019). Improving quality of life for the local community is one of the basic principles of placemaking, and it is what sets it apart from the model of a creative city (Murdoch III et al., 2016; Frenette, 2017).

\section{Critiques of placemaking}

When creative industries and members of the creative class are at the focal point, placemaking becomes very similar to the creative city model (Richards, 2017b). In this case, there is often a disparity between the economic impact and positive social impacts (Stern, 2014). This is reflected in the fact that there are different groups of indicators that measure efficacy depending on whether the focus is on attracting wealthier cultural tourists or addressing the needs of the local community (Zitcer, 2020). The two goals often run counter to each other, which leads to numerous unwanted consequences. These can be divided roughly into two basic groups: homogenization of space and gentrification.

The desire to succeed quickly and the need for positioning in a globalizing world (Richards and Duif, 2018) leads most cities towards adopting well-known models of revitalization, which include flagship architecture, cultural festivals, public art, and art precincts, etc. (Matthews, 2014). The best examples of this are Bilbao and Baltimore (Richards and Duif, 2018).

However, instead of creating a distinction and attracting attention, the end result is often described as standardized (Ghavampour and Vale, 2019),
Umjesto preskriptivnih modela kreativnosti, koji se oslanjaju isključivo na kreativni sektor (Richards, 2019), brojni autori zalažu se za holističko poimanje kreativnosti (Richards, 2019), pri čemu ključna uloga pripada svakodnevnoj kreativnosti (Ghavampour i Vale, 2019), sadržanoj u životnom stilu, načinu provođenja slobodnoga vremena te lokalnim umjetničkim izričajima (u književnosti, glazbi, likovnim umjetnostima) (Richards, 2017b). Maksimiziranje potencijala već prisutnih u zajednici kroz suradnju i partnerstvo (Frenette, 2017) umjesto traganja za stranim talentima (Ghavampour i Vale, 2019) ili isključiva oslanjanja na stručnjake (Razali i dr., 2019) vodi do poboljšanja kvalitete života lokalne zajednice, što je jedno od osnovnih načela koncepta preoblikovanja mjesta te ujedno i razlikovni element u odnosu na model kreativnoga grada (Murdoch III i dr., 2016; Frenette, 2017).

\section{Kritike koncepta preoblikovanja mjesta}

Kad se u središte stavljaju kreativne industrije i pripadnici kreativne klase (Richards, 2017b), koncept preoblikovanja mjesta gotovo je istovjetan modelu kreativnoga grada. Tada često dolazi do rascjepa između ostvarivanja ekonomskih rezultata i postizanja pozitivnih društvenih učinaka (Stern, 2014), što se odražava i u postojanju različitih skupina indikatora za mjerenje učinkovitosti, ovisno o tome stavlja li se naglasak na privlačenje imućnijih kulturnih turista ili na razvoj usmjeren na potrebe lokalne zajednice (Zitcer, 2020). Učestala međusobna suprotstavljenost ovih ciljeva dovodi do brojnih neželjenih posljedica koje okvirno možemo podijeliti u dvije temeljne skupine, jednu koja se odnosi na homogenizaciju prostora te drugu koja se odnosi na poticanje procesa vezanih za gentrifikaciju.

Želja za brzim uspjehom i potreba za pozicioniranjem u globaliziranom svijetu (Richards i Duif, 2018) usmjerava većinu gradova prema usvajanju dobro poznatih modela revitalizacije, što između ostaloga uključuje strateške arhitektonske projekte, kulturna događanja, umjetnost $\mathrm{u}$ javnom prostoru i kulturne četvrti (Matthews, 2014), a za što su ponajbolji primjeri Bilbao i Baltimore (Richards i Duif, 2018).

No umjesto razlikovnoga elementa kao čimbenika privlačnosti rezultat se češce opisuje kao
Placemaking, local community and tourism

Koncept preoblikovanja mjesta, lokalna zajednica i turizam 
unoriginal and duplicated (Zitcer, 2020), generic (Matthews, 2014), predictable (Lew, 2017), and placeless (Relph, 1976). The reason behind this is that too much focus was placed on physical design and infrastructure, while the intangible aspects of place were neglected (Redaelli, 2018; Richards and Duif, 2018; Ghavampour and Vale, 2019), as were the local community's needs and the importance of their active engagement (Matthews, 2014; Lew, 2017; Redaelli, 2018; Richards and Duif, 2018; Ghavampour and Vale, 2019; Platt and Medway, 2020). Heavily relying on expert opinions (Ghavampour and Vale, 2018; Richards and Duif, 2018), mainstream culture, and value systems (Redaelli, 2018; Dupre, 2019; Zitcer, 2020) also contribute to the same result. Instead of having a key function in placemaking, the local culture must contend with the negative consequences of commodification (Richards, 2017b), festivalization (Richards and Duif, 2018), serial reproduction, and fabrication (Richards and Wilson, 2006). The purpose of the local culture is manifested in the "aestheticization of consumption" according to the "just add artists and stir" principle (Matthews, 2014, 1030). Excessive professionalization of creative placemaking initiatives results in homogenization, at least within the context of the United States. According to the opinion of some practitioners, this is partly the result of trying to meet the definitional demands of organizations such as ArtPlace, Kresge Foundation, and National Endowment for the Arts as they fund such projects and therefore determine trends (Zitcer, 2020).

The other criticism is directed at gentrification as an impact of placemaking. It transforms lower income neighborhoods and forces the local population to move out in favor of wealthier people, usually members of the creative class (Lew, 2017). Most authors (Grodach et al.,2014; Wilbur, 2015; Galvis, 2017; Lew, 2017; Richards, 2017b; Richards and Duif, 2018; Zitcer, 2020) have pointed to the displacement of the local, indigenous population due to the increase of costs of living, rent, and real estate. In addition to the social dimension of gentrification, there is also the commercial one. The pre-existing shopping (e.g. corners shop, open street markets) and gastronomic supply with its standardizirajući (Ghavampour i Vale, 2019); neoriginalan i duplicirajući (Zitcer, 2020); generičan (Matthews, 2014), jednak i predvidljiv (Lew, 2017), bezmjesan (Relph, 1976). Uzrok je dvojak i sastoji se u udaljavanju od originalnoga smisla koncepta preoblikovanja mjesta (Ghavampour i Vale, 2019) kroz pretjerani fokus na fizički dizajn i infrastrukturu s istodobnim zanemarivanjem nematerijalnih aspekata prostora (Redaelli, 2018; Richards i Duif, 2018; Ghavampour i Vale, 2019) kao i potreba lokalne zajednice te mogućnosti za njihov aktivan angažman (Matthews, 2014; Lew, 2017; Redaelli, 2018; Richards i Duif, 2018; Ghavampour i Vale, 2019; Platt i Medway, 2020) uslijed pretjerana oslanjanja na mišljenje stručnjaka (Ghavampour i Vale, 2018; Richards i Duif, 2018) te nametanja mainstream kulture i vrijednosnoga sustava (Redaelli, 2018; Dupre, 2019; Zitcer, 2020). Umjesto ključne funkcije u procesu preoblikovanja mjesta lokalna kultura bori se s negativnim posljedicama komodifikacije (Richards, 2017b), festivalizacije (Richards i Duif, 2018), serijske reprodukcije i fabrikacije (Richards i Wilson, 2006), pri čemu se njezin smisao ogleda jedino u „estetizaciji potrošnje” (Matthews, 2014,1030). Pretjerana profesionalizacija inicijativa kreativnoga preoblikovanja mjesta, kao i homogenizacija koja iz nje proizlazi, barem u američkom kontekstu, prema mišljenju pojedinih praktičara dijelom je i rezultat udovoljavanja definicijskim okvirima organizacija poput ArtPlace, Kresge Foundation, National Endowement for the Arts, koje financiraju ovakve projekte te time imaju moć odredivanja trendova (Zitcer, 2020).

Druga skupina kritika odnosi se na gentrifikaciju kao rezultat preoblikovanja mjesta koji uzrokuje transformaciju siromašnijih gradskih četvrti, a time i premještanje lokalnoga stanovništva te naseljavanje imućnijih, najčešće pripadnika kreativne klase (Lew, 2017). Upravo je iseljavanje lokalnoga, starosjedilačkoga stanovništva uslijed povećanih životnih troškova i troškova najma i cijena nekretnina posljedica koju ističe najveći broj autora (Grodach i dr.,2014; Wilbur, 2015; Galvis, 2017; Lew, 2017; Richards, 2017b; Richards i Duif, 2018; Zitcer, 2020). Uz socijalnu dimenziju gentrifikacije ističe se i komercijalna koja se odnosi na zamjenu postojećih trgovačkih i ugostiteljskih sadržaja izraženoga 
distinctively local character is replaced with the one better suited to the taste of global consumer culture (Zukin, 2010; Galvis, 2017; Lew, 2017; Richards and Duif, 2018). Zukin (1995) stated that culture was one of today's most important sites of social conflicts, which was, along with public space, shaped to great extent by people with economic and political power. In the case of Bogota's prevalent planning discourse, which applies different spatial measures to 'free' public spaces from unwanted users such as the homeless or the street vendors, Galvis (2017), similar to Zukin (1995), concluded that the right to the city and quality public spaces is only possessed by those who can afford to enjoy the offered activities therein. Richards (2017b) and Zitcer (2020) agreed that one of the biggest problems of placemaking, particularly creative placemaking, was favoring one group of citizens over another. This causes one group to develop a sense of belonging whereas the other irrevocably loses it. Grodach et al. (2014) found that the arts (especially commercial arts) and art-based creative placemaking initiatives acted as a catalyst for change that largely benefited the elites, thus activating the gentrification process.

\section{Conclusion}

The scientific contribution of this paper is reflected in its comparative review of the literature dedicated to the concept of placemaking, with special emphasis on its application in tourism and community development. In addition, the contribution to the discussion on the value of applying the concept of placemaking in tourism is visible in the analysis of examples of empirical research which are systematically classified with regard to the use of tangible, intangible, or mixed tools of placemaking. A comprehensive review of empirical and review papers shows that the concept of placemaking is of interest to a large number of scientific disciplines. It is therefore not surprising that the content analysis of relevant papers on the definition of the term 'placemaking' has revealed certain similarities, but also differences in the understanding of the core of the concept. The basic similarities concern participation, the processual lokalnog karaktera sadržajima koji bolje odgovaraju globalnom konzumerističkom ukusu (Zukin, 2010; Galvis, 2017; Lew, 2017; Richards i Duif, 2018). Zukin (1995) je mišljenja da je kultura jedno od važnijih poprišta društvenih sukoba te kako nju, baš kao i javni prostor, u najvećoj mjeri oblikuju ljudi s ekonomskom i političkom moći. Na primjeru prevladavajućega diskursa prostornih planera u Bogoti, koji različitim prostornim mjerama nastoje javne prostore osloboditi neželjenih korisnika, poput beskućnika ili uličnih prodavača, Galvis (2017), slično kao Zukin (1995), zaključuje kako pravo na grad i kvalitetne javne prostore imaju samo oni koji posjeduju financijske mogućnosti za uživanje u ponuđenim aktivnostima. Richards (2017b) i Zitcer (2020) slažu se kako je jedan od najvećih problema koncepta preoblikovanja mjesta, posebno kreativnoga, upravo favoriziranje jedne skupine građana naspram druge, pri čemu jedni razvijaju osjećaj pripadnosti, dok ga drugi nepovratno gube. Grodach i dr. (2014) primijetili su da umjetnosti i inicijative kreativnoga preoblikovanja mjesta na njima zasnovane djeluju poput katalizatora promjena koje najviše pogoduju elitama, pri čemu se osobito komercijalne umjetnosti povezuju s izraženom gentrifikacijom.

\section{Zaključak}

Znanstveni doprinos ovoga rada ogleda se u komparativnom pregledu literature posvećene konceptu preoblikovanja mjesta s posebnim naglaskom na njegovu primjenu u turizmu i razvoju lokalne zajednice. $\mathrm{K}$ tomu je doprinos diskusiji o vrijednosti primjene koncepta preoblikovanja mjesta u turizmu vidljiv i u provedenoj analizi primjera empirijskih istraživanja koja su sustavno klasificirana s obzirom na korištenje materijalnih, nematerijalnih ili mješovitih alata preoblikovanja mjesta. Opširnim pregledom empirijskih i preglednih istraživanja primjećuje se da je koncept preoblikovanja mjesta predmet interesa velikoga broja znanstvenih disciplina. $\mathrm{Ne}$ čudi stoga što je sadržajna analiza relevantnih radova o definiciji koncepta preoblikovanja mjesta pokazala određene sličnosti, ali i razlike u shvaćanju srži koncepta. Temeljna zajednička obilježja odnose se na participativnost, procesnost i holizam, međusektorsku suradnju, uključivanje lokalne zajednice
Placemaking, local community and tourism

Koncept preoblikovanja mjesta, lokalna zajednica i turizam 
GEOGRAFSKI

GLASNIK

83/1,77-104 (2021.) and holistic approach, cross-sectoral cooperation, the involvement of the local community through the co-creative process and the impact on the quality of life.

Apart from economic development as a kind of by-product, the effects of placemaking are most evident at the spatial and social levels. Negative effects can be divided into two basic groups and relate to the homogenization of space and the activation of the gentrification process. Positive social impacts relate primarily to the improvement of quality of life, which is reflected in an increase in social capital and social cohesion, i.e. the creation of stronger ties within the community as well as the community with the place. Looking at the dimension of physical space, we concluded that placemaking improves the appearance of the place and stimulates long-term physical regeneration, creating an attractive, interesting, safe and comfortable environment with a wide range of $\mathrm{fa}$ cilities.

Many studies have shown that these changes influenced the increase in satisfaction of the residents and also attracted future residents, investors, and tourists, on social and spatial levels. This is especially the case when we look at new trends in tourism based on fulfilling, meaningful experiences resulting from the co-creative process and the desire to get to know local people, places, culture, tradition, and everyday practices. In this light, and despite the elusiveness of the concept due to its different definitions and a wide range of related issues, the concept of placemaking can serve as a useful analytical category for a more systematic study of spatial transformations, especially those caused by tourism, but also as a development tool in strategic tourism planning.

\section{Acknowledgement}

Zahvala
This paper was created as part of an internal scientific project of the Institute for Tourism: The role of niche tourism in destination development: example of culture, arts and sports (K.U.S.T. 2021). I would like to thank to my $\mathrm{PhD}$ supervisor prof. Vuk Tvrtko Opačić, $\mathrm{PhD}$ and two anonymous reviewers for their useful comments and suggestions. kroz sustvaralački proces te utjecaj na kvalitetu života.

Osim ekonomskoga razvoja, kao svojevrsna nusprodukta, učinci koncepta preoblikovanja mjesta najviše se očituju na prostornoj razini te u društvenoj domeni, s obzirom na njegovu usku povezanost sa specifičnim potrebama pojedine lokalne zajednice. Negativni učinci mogu se podijeliti u dvije temeljne skupine i odnose se na homogenizaciju prostora i aktivaciju procesa gentrifikacije. Pozitivni društveni učinci odnose se u prvom redu na poboljšanje kvalitete života što se odražava u povećanom socijalnom kapitalu i socijalnoj koheziji, odnosno stvaranju čvršćih veza unutar zajednice, kao i zajednice s prostorom. Promatrajući dimenziju fizičkoga prostora, zaključuje se da koncept preoblikovanja mjesta utječe na poboljšanje izgleda prostora te stimulaciju dugoročne fizičke regeneracije, kao i stvaranje atraktivna, zanimljiva, sigurna i udobna okruženja ispunjena raznovrsnim sadržajima.

Analizirana istraživanja pokazuju da navedene promjene na društvenoj i prostornoj razini utječu na povećanje zadovoljstva i privlačenje kako postojećih tako i budućih stanovnika, zatim investitora te svakako turista, posebice ako se uzmu u obzir novi trendovi u turizmu koji počivaju na ispunjujućim doživljajima i iskustvima koja proizlaze iz sustvaralačkoga procesa te želje za upoznavanjem lokalnog - ljudi, prostora, kulture, tradicije, svakodnevnih praksa. S obzirom na navedeno, unatoč neuhvatljivosti koncepta uslijed njegova različita definiranja te širokoga dijapazona tema koje se s njim povezuju, preoblikovanje mjesta može poslužiti kao korisna analitička kategorija u svrhu sustavnijega istraživanja prostornih transformacija, posebno onih izazvanih turizmom, ali i kao razvojni alat u strateškom planiranju turizma.

Ovaj je rad izrađen u sklopu internoga znanstvenog projekta Instituta za turizam: Uloga posebnih oblika turizma u razvoju destinacije: primjer kulture, umjetnosti i sporta (K. U. S. T. 2021). Željela bih zahvaliti mentoru doktorske disertacije prof. dr. sc. Vuku Tvrtku Opačiću i dvama anonimnim recenzentima na korisnim komentarima i prijedlozima. 
Alderman, D. H., Benjamin, S. K., Schneider, P. P., 2012: Transforming Mount Airy into Mayberry: Film-Induced Tourism as Place-Making, Southeastern Geographer 52 (2), 212-239, DOI:10.1353/sgo.2012.0016.

Ali, M., 2017: 'Art is not just about entertainment': the social activism and cultural production of Chicago's Inner-City Muslim Action Network (IMAN), Culture and Religion 18 (4), 353-370, DOI:1 0.1080/14755610.2017.1377982.

Arsenault, N., 2019: The Power of Stories in Tourism, in Jelinčić, D. A., Mansfeld, Y. (eds.): Creating and Managing Experiences in Cultural Tourism, World Scientific, Singapore, 173-189, DOI: 10.1142/9789813233683_0011.

Baka, V., 2015: Understanding Valuing Devices in Tourism through "Place-making”, Valuation Studies 3 (2), 149-180, DOI:10.3384/VS.2001-5992.1532149.

Balassiano, K., Maldonado, M. M., 2015: Placemaking in rural new gateway communities, Community Development Journal 50 (4), 644-660, DOI:10.1093/cdj/ bsu064.

Ball, R., 2014: Economic Development: It's About Placemaking, The European Business Review, https://www.europeanbusinessreview.com/economic-development-its-about-placemaking/ (26. 7. 2020.).

Barrera-Fernández, D., Hernández-Escampa, M., 2017: Events and placemaking: the case of the Festival Internacional Cervantino in Guanajuato, Mexico, International Journal of Event and Festival Management 8 (1), 24-38, DOI:10.1108/IJEFM-05-2016-0041.

de Britto, M. P., Richards, G., 2017: Guest editorial: Events and placemaking, International Journal of Event and Festival Management 8 (1), 2-7, DOI: 10.1108/ IJEFM-01-2017-0007.

van der Borg, J., Costa, P., Gotti, G., 1996: Tourism in European heritage cities, $A n$ nals of Tourism Research 23 (2), 306-321, DOI:10.1016/0160-7383(95)00065-8.

Brownett, T., Evans, O., 2020: Finding common ground: The conception of community arts festivals as spaces for placemaking, Health \& Place 61, (1-8), DOI:10.1016/j.healthplace.2019.102254.

Brunnberg, L., Frigo, A., 2012: Placemaking in the 21st-century city: introducing the funfair metaphor for mobile media in the future urban space, Digital Creativity 23 (2), 113-125, DOI:10.1080/14 626268.2012.709943.

Buser, M., Bonura, C., Fannin, M., Boyer, K., 2013: Cultural activism and the politics of place-making, City 17 (5), 606-627, DOI:10.1080/13604813.201 3.827840 .

Butterworth, I., 2000: The Relationship Between the Built Environment and Wellbeing: a Literature Review, http:// hiaconnect.edu.au/old/files/Built_Environment_\%26_Wellbeing.pdf (12. 7. 2020.)

Careva, K., Lisac, R., Pletenac, T., Vukić, J., 2017: Akupunktura grada kao participativni alat za revitalizaciju javnog prostora, Prostor: znanstveni časopis za arbitekturu i urbanizam 25 (2(54)), 190-199, DOI:10.31522/p.25.2(54).2.

Christou, A., 2017: Bottom-up placemaking in a time of crisis, by the people, for the people: Case study of Arillas, Corfu, Journal of Place Management and Development 10 (2), 173-182, DOI:10.1108/ JPMD-07-2016-0048.

Cilliers, E. J., Timmermans, W., 2014: The Importance of Creative Participatory Planning in the Public Place-Making Process, Environment and Planning B: Planning and Design 41 (3), 413-429, DOI:10.1068/b39098.

Cilliers, E. J., Timmermans, W., Van den Goorbergh, F., Slijkhuis, J. S. A., 2015: The Story Behind the Place: Creating Urban Spaces That Enhance Quality of Life, Applied Research Quality Life 10 (4), 589-598, DOI:10.1007/s11482014-9336-0.

Coghlan, A., Sparks, B., Liu, W., Winlaw, M., 2017: Reconnecting with place through events: Collaborating with precinct managers in the placemaking agenda, International Journal of Event and Festival Management 8 (1), 66-83, DOI:10.1108/IJEFM-06-2016-0042.

Couret, C., 2019: From the Tourist Experience Design to Holistic Destination Management, in Jelinčić, D. A., Mansfeld, Y. (eds.): Creating and Managing Experiences in Cultural Tourism, World Scientific, Singapore, 321-338, DOI:10.1142/9789813233683_0020.

Cresswell, T., 2004: Place: A Short Introduction, Blackwell Publishing, Oxford.

Daniel, J. L., Kim, M., 2020: Creative
Placemaking: Creating Change by Building Partnerships, Journal of Public and Nonprofit Affairs 6 (1), 96-110, DOI:10.20899/jpna.6.1.96-110.

Derrett, R., 2003: Making Sense of How Festivals Demonstrate a Community's Sense of Place, Event Management 8 (1), 49-58, DOI:10.3727/152599503108751694.

Dodd, D., 2019: The S Plan, in Jelinčić, D. A., Mansfeld, Y. (eds.): Creating and Managing Experiences in Cultural Tourism, World Scientific, Singapore, 19-204, DOI:10.1142/9789813233683_0012.

Dupre, K., 2019: Trends and gaps in place-making in the context of urban development and tourism: 25 years of literature review, Journal of Place Management and Development 12 (1), 102120, DOI:10.1108/JPMD-07-20170072.

Durmaz, B., Platt, S., Yigitcanlar, T., 2010: Creativity, culture tourism and place-making: Istanbul and London film industries, International Journal of Culture, Tourism and Hospitality Research 4 (3), 198-213, DOI:10.1108/17506181011067592.

Duxbury, N., Richards, G., 2019: Towards a research agenda for creative tourism: developments, diversity, and dynamics, in Duxbury, N., Richards, G. (eds.): $A$ Research Agenda for Creative Tourism, Edwar Elgar Publishing, Cheltenham, 1-14, DOI:10.4337/9781788110723.

Duxbury, N., Silva, S., Vinagare de Castro, T., 2019: Creative Tourism Development in Small Cities and Rural Areas in Portugal: Insights from Start-Up Activities, in Jelinčić, D. A., Mansfeld, Y. (eds.): Creating and Managing Experiences in Cultural Tourism, World Scientific, Singapore, 291-304, DOI:10.1142/9789813233683_0018.

Ellery, P. J., Ellery, J., 2019: Strengthening Community Sense of Place through Placemaking, Urban Planning 4 (2), 237-248, DOI:10.17645/up.v4i2.2004.

Florida, R., 2002: The Rise Of The Creative Class: And How It's Transforming Work, Leisure, Community And Everyday Life, Basic Books, New York.

Frangos, M., Garvey, T., Knezevic, I., 2017: Infrastructuring Place. Citizen-led Placemaking and the Commons, The Design Journal 20 (sup1), S3279-S3293, DOI:10.1080/14606925.2017.1352832.

Placemaking, local community and tourism

Koncept preoblikovanja mjesta, lokalna zajednica i turizam

Literature Literatura 
GEOGRAFSKI

GLASNIK

83/1,77-104 (2021.)
Franklin, A., Marsden, T., 2015: (Dis) connected communities and sustainable place-making, Local Environment 20 (8), 940-956, DOI:10.1080/13549839.2013 .879852 .

French, T., 2018: Keying In: Getting Close to 186 Carpenter, Creative Placemaking, and the Artist Entrepreneur, Artivate: A Journal of Entrepreneurship in the Arts 7 (1), 49-62.

Frenette, A., 2017: The Rise of Creative Placemaking: Cross-Sector Collaboration as Cultural Policy in the United States, The Journal of Arts Management, Law, and Society 47 (5), 333-345, DOI:1 0.1080/10632921.2017.1391727.

Friedmann, J., 2010: Place and Place-Making in Cities: A Global Perspective, Planning Theory \& Practice 11 (2), 149-165, DOI:10.1080/14649351003759573.

Gadwa Nicodemus, A., 2013: Fuzzy vibrancy: Creative placemaking as ascendant US cultural policy, Cultural Trends 22 (3-4), 213-222, DOI:10.1080/09548 963.2013.817653.

Gallagher, B. K., Ehlman, M. P., 2019: Arts at the Intersection: Cross-Sector Collaboration and Creative Placemaking in Rapid City, SD, Public Performance E Management Review 42 (6), 1333-1350, DOI:10.1080/15309576.2019.1601113.

Galvis, J. P., 2017: Planning for Urban Life: Equality, Order, and Exclusion in Bogotá's Lively Public Spaces, Journal of Latin American Geography 16 (3), 83105, DOI:10.1353/lag.2017.0046.

Ghavampour, E., Vale, B., 2019: Revisiting the "Model of Place": A Comparative Study of Placemaking and Sustainability, Urban Planning 4 (2), 196-206, DOI:10.17645/up.v4i2.2015.

Gilbert, D., Dwyer, C., Ahmed, N., Graces, L. C., Hyacinth, N., 2018: The hidden geographies of religious creativity: place-making and material culture in West London faith communities, Cultural Geographies, 1-19, DOI:10.1177/1474474018787278.

Grodach, C., Foster, N., Murdoch III, J., 2014: Gentrification and the Artistic Dividend: The Role of the Arts in Neighborhood Change, Journal of the American Planning Association 80 (1), 21-35, DOI:10.1080/01944363.2014.9 28584.

Gulin Zrnić, V., 2004: Moj dom: stvaranje mjesta u novozagrebačkom prostoru/
My home: place making in the area of Novi Zagreb, Život umjetnosti: časopis za suvremena likovna zbivanja 38 (73), 40-53 .

Gulin Zrnić, V., Škrbić Alempijević, N., Zanki, J. (eds.), 2016: Mjesto izvedbe i stvaranje grada, Hrvatsko društvo likovnih umjetnika, Institut za etnologiju i folkloristiku, Zagreb.

Gulin Zrnić, V., Rubić, T., 2018: City-making through Urban Gardening: Public Space and Civic Engagement in Zagreb, Narodna umjetnost: hrvatski časopis za etnologiju i folkloristiku 55 (1), 159-179, DOI:10.15176/vol55no109.

Gulin Zrnić, V., Škrbić Alempijević, N., 2019: Grad kao susret. Etnografije zagrebačkih trgova, Hrvatsko etnološko društvo, Institut za etnologiju i folkloristiku, Zagreb.

Hampton, M. P., 2005: Heritage, local communities and economic development, Annals of Tourism Research 32 (3), 735-759, DOI: 10.1016/j.annals.2004.10.010

Haraldseid, T., 2019: Exploring social creativity in place-making: A case study from a coastal town in Northern Norway, Norsk Geografisk Tidsskrift - Norwegian Journal of Geography 73 (5), 257-272, DOI:10.1080/00291951.202 0.1716844 .

Houghton, K., Foth, M., Miller, E., 2015 Urban Acupuncture: Hybrid Social and Technological Practices for Hyperlocal Placemaking, Journal of Urban Technology 22 (3), 3-19, DOI:10.1080/106307 32.2015.1040290.

Hultman, J., Hall, C. M., 2012: Tourism place-making: Governance of Locality in Sweden, Annals of Tourism Research 39 (2), 547-570, DOI:10.1016/j.annals.2011.07.001

Jażdżewska, I., 2017: Murals as a tourist attraction in a post-industrial city: a case study of Łódź (Poland), Turyzm/ Tourism 27 (2), 45-56, DOI:10.1515/ tour-2017-0012.

Jelinčić, D. A., Senkić, M., 2017: Creating a Heritage Tourism Experience. The Power of the Senses, Etnološka tribina: Godišnjak Hrvatskog etnološkog društva 47 (40), 109-126, DOI:10.15378/18489540.2017.40.03.

Jelinčić, D. A., Vukić, F., Kostešić, I., 2017: The City is more than just a Destination: An Insight into City Branding Practices in Croatia, Sociologija i prostor: časopis $z a$ istraživanje prostornoga $i$ sociokulturnog razvoja 55 (1(207)), 117-134, DOI:10.5673/sip.55.1.6.

Kavaratzis, M., Ashworth, G. J., 2005 City Branding: An Effective Assertion of Identity or a Transitory Marketing Trick?, Tijdschrift voor economische en sociale geografie 96 (5), 506-514, DOI:10.1111/j.14679663.2005.00482.x

Kelemen, P., Škrbić Alempijević, N., 2012: Grad kakav bi trebao biti. Etnološki i kulturnoantropološki osvrti na festivale, $\mathrm{Nak}$ lada Jesenski i Turk, Zagreb.

Kelemen, P., 2018: "Now I am in love with the city". Emotions, affects and place-making practices of international migrants in Zagreb, in Book of Abstracts of $9^{\text {th }}$ InASEA Conference. Emotions, Senses and Affect in the Context of Southeast Europe, Zadar, http://conference. unizd.hr/inasea2018/wp-content/uploads/sites/18/2018/09/Book-of-Abstracts-InASEA2018.pdf-final.pdf (11. 9. 2020.).

Kelkar, N. P., Spinelli, G., 2016: Building social capital through creative placemaking, Strategic Design Research Journal 9 (2), 54-66, DOI:10.4013/ sdrj.2016.92.01.

Kelly, J., Ruther, M., Ehresman, S., Nickerson, B., 2017: Placemaking as an Economic Development Strategy for Small and Midsized Cities, $U r-$ ban Affairs Review 53 (3), 435-462, DOI:10.1177/1078087416657895.

Kolås, Å., 2004: Tourism and the Making of Place in Shangri-La, Tourism Geographies 6 (3), 262-278, DOI:10.1080/1461 668042000249610

Laven, J., Bradley, A. L., Polyak, L., 2019: Placemaking in the European context. The movement is here to stay, The Journal of Public Space 4 (1), 135-154, DOI:10.32891/jps.v4i1.1159.

Lefebvre, H., 1991: The production of space, Blackwell Publishing, Oxford

Lew, A. A., 2017: Tourism planning and place making: place-making or placemaking?, Tourism Geographies 19 (3), 448-466, DOI:10.1080/14616688.201 7.1282007.

Maidment, J., Tudor, R., Campbell, A., Whittaker, K., 2019: Women's place-making through craft in post-earthquake Christchurch, Aotearoa 
New Zealand Social Work 31 (1), 17-30, DOI:10.11157/anzswj-vol31iss1id557.

Mansfeld, Y., 2019: Pursued Cultural Sustainability and Sought Cultural Experiences: Host-Guest Perspectives, in Jelinčić, D. A., Mansfeld, Y. (eds.): Creating and Managing Experiences in Cultural Tourism, World Scientific, Singapore, 241-253, DOI:10.1142/9789813233683_0015.

Markusen, A., Gadwa, A., 2010: Creative Placemaking. A White Paper for The Mayors'Institute on City Design, a leadership initiative of the National Endowment for the Arts in partnership with the United States Conference of Mayors and American Architectural Foundation, https://www.a2ru.org/wp-content/ uploads/2018/10/white-paper-creative-placemaking-1.pdf (11. 9. 2020.).

Markusen, A., 2014: Creative Cities: A 10Year Research Agenda, Journal of Urban Affairs 36 (s2), 567-589, DOI:10.1111/ juaf.12146.

Marques, L., Richards, G., 2014: The Dimensions of Art in Place Narrative, Tourism Planning \& Development 11 (1), 1-12, DOI:10.1080/21568316.2013.85 2990.

Mathews, V., 2014: Incoherence and Tension in Culture-Led Redevelopment, International Journal of Urban and Regional Research 38 (3), 1019-1036, DOI:10.1111/1468-2427.12108.

Mokras-Grabowska, J., 2014: Art-tourism space in Eódź: The example of the Urban Forms Gallery, Turyzm/Tourism 24 (2), 23-30, DOI:10.2478/tour-2014-0013.

Moscardo, G., 1996: Mindful visitors: Heritage and tourism, Annals of Tourism Research 23 (2), 376-397, DOI:10.1016/0160-7383(95)00068-2.

Murdoch III, J., Grodach, C., Foster, N., 2016: The Importance of Neighborhood Context in Arts-Led Development: Community Anchor or Creative Class Magnet?, Journal of Planning Education and Research 36 (1), 32-48, DOI: 10.1177/0739456X15599040.

O’Rourke, V., Baldwin, C., 2016: Student engagement in placemaking at an Australian university campus, Australian Planner 53 (2), 103-116, DOI:10.1080 /07293682.2015.1135810.

Pearce, P. L., Wu, M.-Y., 2015: Soft infrastructure at tourism sites: identifying key issues for Asian tourism from case studies, Tourism Recreation Research 40 (1), 120-132, DOI:10.1080/02508281. 2015.1010361.

Platt, L. C., 2017: Crafting place: Women's everyday creativity in placemaking processes, European Journal of Cultural Studies 116, DOI:10.1177/1367549417722090.

Platt, L. C., Medway, D., 2020: Sometimes. . Sometimes. . . Sometimes. . . Witnessing Urban Placemaking from the Immanence of "the Middle", Space and Culture 1-16, DOI:10.1177/1206331219896261.

Popović, S. G., Lipovac, N., Vlahović, S., 2016: Planiranje i stvaranje prepoznatljivosti mjesta grada Podgorice očitano kroz povijesne urbanističke planove, Prostor: znanstveni časopis za arbitekturu i urbanizam 24 (1(51)), 62-73, DOI:10.31522/p.24.1(51).5.

Pritchard, A., Morgan, N., Ateljevic, I., 2011: Hopeful tourism: A New Transformative Perspective, Annals of Tourism Research 38 (3), 941-963, DOI:10.1016/j.annals.2011.01.004.

Project for Public Spaces (2009, August 2), Eleven Principles for Creating Great Community Places, https://www.pps. org/article/11steps (3. 6. 2019.).

Project for Public Spaces (2012, November 12), Placemaking and the Future of Cities, https://www.pps.org/article/ placemaking-and-the-future-of-cities (27. 5. 2019.).

Radney, E.-R. A., 2019: A Place in the Sun: Black Placemaking in Pan African Detroit, Journal of Black Studies 50 (3), 316340, DOI:10.1177/0021934719834696.

Razali, M. K., Ismail, H. N., 2014: Tourism Place-Making at Tourism Destination from a Concept of Governance, International Conference IGCESH2014, Universiti Teknologi Malaysia, Johor Bahru, Malezija, 172-177, https://core.ac.uk/ reader/83531440 (11. 9. 2020.).

Razali, M. K., Ahmad, H., Er, A.-C., 2019: The Analysis of Place-Making Research Towards Community Sustainability in Malaysia, International Journal of Business and Society 20 (1), 329-347.

Redaelli, E., 2016: Creative placemaking and the NEA: unpacking a multi-level governance, Policy Studies 37 (4), 387402, DOI:10.1080/01442872.2016.11 57857.
Redaelli, E., 2018: Creative placemaking and theories of art: Analyzing a placebased NEA policy in Portland, OR, Cities 72, 403-410, DOI:10.1016/j.cities.2017.10.001.

Relph, E. C., 1976: Place and Placelessness, Pion, London.

Richards, G., 2011: Creativity and tourism: The State of the Art, Annals of Tourism Research 38 (4), 1225-1253, DOI:10.1016/j.annals.2011.07.008.

Richards, G., 2017a: From place branding to placemaking: the role of events, International Journal of Event and Festival Management 8 (1), 8-23, DOI:10.1108/ IJEFM-09-2016-0063.

Richards, G.2017b: Making places through creative tourism?, https://www.researchgate.net/publication/320420771_Making_places_through_creative_tourism (3. 4. 2020.).

Richards, G., 2018: Tourism, an Underestimated Driving Force for the Creative Economy, Revista Turismo em Análise - RTA 29 (3), 387-395, DOI:https:// doi.org/10.11606/issn.1984-4867. v29i3p387-395.

Richards, G., 2019: Creative tourism: opportunities for smaller places?, Tourism E Management Studies 15 (SI), 7-10, DOI: $10.18089 / \mathrm{tms} .2019 .15 \mathrm{SI} 01$

Richards, G., Duif, L., 2018: Small Cities with Big Dreams: Creative Placemaking and Branding Strategies, Routledge, New York.

Richards, G., Wilson, J., 2006: Developing creativity in tourist experiences: A solution to the serial reproduction of culture?, Tourism Management 27 (6), 1209-1223, DOI:10.1016/j.tourman.2005.06.002.

Rosner-Manor, Y., Borghini, S. G., Boonstra, B., Silva, P., 2019: Adaptation of the urban codes - A story of placemaking in Jerusalem, Environment and Planning B: Urban Analytics and City Science, 1-17, DOI:10.1177/2399808319867712.

Rota, F. S., Salone, C., 2014: Place-making processes in unconventional cultural practices. The case of Turin's contemporary art festival Paratissima, Cities 40,9098, DOI:10.1016/j.cities.2014.03.008.

Selberg, T., Škrbić Alempijević, N., 2013: Kako fikciju pretvoriti u stvarnost: stvaranje dvaju mjesta u književnoj geografiji, Studia ethnologica Croatica 25 (1), 183-206.
Placemaking, local community and tourism

Koncept preoblikovanja mjesta, lokalna zajednica i turizam 
GEOGRAFSKI

GLASNIK

83/1,77-104 (2021.)
Shearmur, R., 2018: Placemaking: what is it and why it it necessary?, https://www.researchgate.net/publication/325323533_ Placemaking_what_is_it_and_why_it_ it_necessary (12.3. 2019.).

Sitte, C., 2010: Gradogradnja prema umjetničkim načelima, Litteris, Zagreb.

Sofield, T., Guia, J., Specht, J., 2017: Organic 'folkloric' community driven place-making and tourism, Tourism Management 61, 1-22, DOI:10.1016/j. tourman.2017.01.002.

Sol, H., de Brito, M. P., Coelho, J. P., Figueira, L. M., Pratt, C., Lopes, E. R., 2017: Rooting a new event in its place: the case of Festa Templária, Tomar, Portugal, International Journal of Event and Festival Management 8 (3), 324-345, DOI:10.1108/IJEFM-10-2016-0068.

Stern, M., 2014: Measuring the Outcomes of Creative Placemaking, https://repository.upenn.edu/siap_placemaking/1 (11. 9.2020.)

Strydom, W., Puren, K., Drewes, E., 2018 Exploring theoretical trends in placemaking: towards new perspectives in spatial planning, Journal of Place Management and Development 11 (2), 165180, DOI:10.1108/JPMD-11-20170113

Sundbo, J., Sundbo, D., 2019: Gastronomy as a Means to Sustainable Tourism Development in Peripheral Destinations: Triple Helix as a Driver, in Jelinčić, D. A., Mansfeld, Y. (eds.): Creating and Managing Experiences in Cultural Tourism, World Scientific, Singapore, 255-271, DOI:10.1142/9789813233683_0016.

Sutherland, F., 2015: Community-driven mining heritage in the Cuyuna Iron Mining District: Past, present, and future projects, The Extractive Industries and Society 2 (3), 519-530, DOI:10.1016/j. exis.2015.04.003
Škrbić Alempijević, N., Oroz, T., 2018 Heroic Topographies. Hero-making and Place-making in Hrvatsko Zagorje, in Vukov, N., Kazalarska, S. (eds.): Heroic Art and Socialist Realism: Monuments, Memory and Representations of the Socialist Past after 1989, Cultural Arcs Foundation, Sofia, 35-55.

Šmid Hribar, M., Bole, D., Pipan, P., 2015 Sustainable Heritage Management: Social, Economic and Other Potentials of Culture in Local Development, Procedia - Social and Behavioral Sciences 188, 103-110, DOI:10.1016/j.sbspro.2015.03.344

Teder, M. E., 2019: Placemaking as co-creation - professional roles and attitudes in practice, CoDesign 15 (4), 289-307, DOI:10.1080/15710882.2018.1472284.

Thurlow, C., Jaworski, A., 2014: 'Two hundred ninety-four': Remediation and multimodal performance in tourist placemaking, Journal of Sociolinguistics 18 (4), 459-494, DOI:10.1111/ josl.12090.

Vaništa Lazarević, E., Koružnjak, A. B., Devetaković, M., 2016: Culture design-led regeneration as a tool used to regenerate deprived areas. BelgradeThe Savamala quarter; reflections on an unplanned cultural zone, Energy and Buildings 115, 3-10, DOI:10.1016/j.enbuild.2015.03.015

Vazquez, L., 2012: Creative placemaking: Integrating community, cultural and economic development. A white paper for leaders, researchers, instructors and practitioners to help build the field of creative placemaking, https://papers. ssrn.com/sol3/papers.cfm?abstract_ $\mathrm{id}=2474862$, (11. 9. 2020.).

Webb, D., 2014: Placemaking and Social Equity: Expanding the Framework of Creative Placemaking, Artivate: A Journal of Entrepreneurship in the Arts 3 (1), $35-48$
Wilbur, S., 2015: It's about Time: Creative placemaking and performance analytics, PerformanceResearch20(4),96-103,DOI: 10.1080/13528165.2015.1071046.

Wise, N., Đurkin, J., Perić, M., 2019: Renewing Rijeka for 2020. Managing placemaking, regeneration, and community participation, in Wise, N., Harris, J. (eds.): Events, places and societies, Routledge, Abingdon, Oxon, 72-84.

Wyckoff, M. A., 2014: Definition of Placemaking: Four Different Types, http:// www.pznews.net/media/13f25a9fff4cf18ffff8419ffaf2815.pdf (11. 9. 2020.).

Wyckoff, M. A., Neumann, B., Pape, G. Schindler, K., 2015: Placemaking as an economic development tool: A Placemaking Guidebook, Michigan State University, East Lansing.

Wynn, J. R., Yetis-Bayraktar, A., 2016: The Sites and Sounds of Placemaking: Branding, Festivalization, and the Contemporary City, Journal of Popular Music Studies 28 (2), 204-223, DOI:10.1111/ jpms.12169.

Zhao, L., 2019: The Sense of Place for Tourists: Place-making Under the Perspectives of Symbolic Interaction and Phenomenology, in Proceedings of $2^{\text {nd }}$ International Conference on Economy, Management and Entrepreneurship (ICOEME 2019), Atlantis Press, 598605, DOI:10.2991/icoeme-19.2019.112

Zitcer, A., 2020: Making Up Creative Placemaking, Journal of Planning Education and Research 40 (3), 278-288, DOI:10.1177/0739456X18773424.

Zukin, S., 1995: The Cultures of Cities, Blackwell Publishers, Oxford.

Zukin, S., 2010: Naked City: The Death and Life of Authentic Urban Places, Oxford University Press, New York.
Author Autor
Ives Vodanović Lukić ives.vodanovic@izzzg.hr MSc in Geography, MA in Art History and Comparative Literature, Research Assistant, Insitiute for Tourism, Vrhovec 5 , 10000 Zagreb, Croatia 